\title{
III. SUBJECT INDEX *
}

A.

Elementary algebra; theory of algebraic and transcendental equations; Galois groups; rational fractions; interpolation.

A, H, I, J, Q, Mathematical problems, D. HiLBERT, translated by M. W. Newson, (2) vIII, 437-479.

A3, Gauss's third proof of the fundamental theorem of algebra, M. BôCHER, (2) I, 205-209.

A3, (M18, (2) vIII, 392-399).

A3j, (H5g, (2) Iv, 256-258, 426-438).

A3k, Final formulas for the algebraic solution of quartic equations, M. Merriman, May 7, 1892, I, 202-205.

A3k, On a solution of the biquadratic which combines the methods of Descartes and Euler, E. McClInTock, May 29, 1897, (2) III, 389390 ; Errata, (2) IV, 283.

A3k, 4a, A solution of the biquadratic by binomial resolvents, G. P. Stark Weather, Apr. 30, 1898, (2) IV, 524-528.

A4, (I3, (2) x, 23-30, 30-31 ; V8, (2) I, 196-204; V9, (2) IV, 332-340).

A4d, J4f, $\mathbf{M}^{2} 3 \mathrm{~d}$, The configurations of the 27 lines on a cubic surface and the 28 bitangents to a quartic curve, L. E. Drckson, Aug. 20, 1901, (2) vIII, 63-70.

A4d, (F5d, (2) III, 279-292).

A4e, On the Ruffini-Abelian theorem, J. Pierpont, (2) II, 200-221.

A, B, J4, Weber's Algebra, J. Pierpont, (2) IV, 200-234. (Lehrbuch der Algebra, H. Weber, 1895-1896.)

A, The new edition of Weber's Algebra, J. Pierpont, (2) v, 480-482. (Lehrbuch der Algebra, H. Weber, 1898-1899.)

A, Bauer's Algebra, L. E. Dickson, (2) X, 257-260; Erratum, 362. (Vorlesungen über Algebra, G. Bauer, 1903.)

A1, V, Shorter notice, G. Eneström, translated by H. JACOBY, I, 26. (The number system of algebra, H. B. Fine, 1891.)

A3, The theory of equations, T. S. Fiske, II, 11-12. (An elementary course in the theory of equations, C. H. Chapman, 1892.)

A3, Shorter notice, J. Maclay, (2) vi, 400-402. (An elementary treatise on the theory of equations, S. M. Barton, 1899.)

* The classification is that of the Index du Répertoire bibliographique des Sciences mathématiques, deuxième édition, Paris, Gauthier-Villars, 1898. Under each main heading original papers are separated from reviews by a rule. The dates attached to original papers are those of their presentation before the Society. Reviews are classified according to their own material, not according to that of the works reviewed. 
A3, 4, Vogt's Algebraic solution of equations, J. Pierpont, (2) vi, 344348. (Leçons sur la résolution algébrique des équations, H. Vogt, 1895.)

A3,4, Shorter notice, G. A. Mrrler, (2) x, 411. (Introduction to the theory of algebraic equations, L. E. Dickson, 1903.)

A4, The Galois theory in Burnside and Panton's Theory of equations, B. S. Easton, (2) viII, 349-351.

A4, (I, (2) III, 97-105;J4a, b, c, II, 83-106.)

A5b, X, Shorter notice, E. W. Brown, (2) vr, 402-404. (The theory and practice of interpolation, H. L. Rice, 1899.)

\section{B.}

Determinants; linear substitutions; elimination; algebraic theory of forms; invariants and covariants; quaternions, equipollences, and complex quantities.

B1, J1aa, Three notes on permutations, F. MoRLEy, III, 142-148.

B1, (D1b, c, II, 135-144.)

B1a, 12d, Determinants of quaternions, J. M. Peirce, Feb. 25, 1899, (2) $v, 335-337$.

B1c, 2, The largest linear homogeneous group with an invariant Pfaffian, L. E. Dickson, Oct. 29, 1898, (2) v, 338-342.

B1c, Note on irregular determinants, L. I. HEwEs, (2) Ix, 141-142.

B1Ca, Kronecker's linear relation among minors of a symmetric determinant, H. S. WHJTE, Jan. 25, 1896, (2) II, 136-138.

B2, On orthogonal substitutions, H. TABER, June 2, 1894, III, 251-259.

B2, 11, Notes on the theory of bilinear forms, H. TABER, Nov. 28, 1896, (2) III, 156-164.

B2, J4, P6, Continuous groups of circular transformations, H. B. Newson, Apr. 24, 1897, (2) IV, 107-121 ; Correction, (Chicago) Jan. 2, 1903, (2) x, 191-193.

B2, J4f, Concerning a linear homogeneous group in $C_{m, q}$ variables isomorphic to the general linear homogeneous group in $m$ variables, L. E. Dickson, Aug. 20, 1898, (2) v, 120-135.

B2, Report on the recent progress in the theory of linear groups, L. E. Dickson, (2) vI, 13-27.

B2, A class of simply transitive linear groups, L. E. Drckson, (2) VIII, 394-401.

B2c, J4a, Concerning Jordan's linear groups, E. H. MoonE, Aug. 28, 1895, (2) II, 33-43.

B2c, Orthogonal group in a Galois field, L. E. Dickson, Dec. 29, 1897, (2) IV, 196-200.

B2c, Isomorphism between certain systems of simple linear groups, L. E. Dickson, Feb. 24, 1900, (2) vi, 323-328.

B2c, (J4f, (2) vIr, 340-350).

B2ca, d, Systems of simple groups derived from the orthogonal group, L. E. Drckson, (Chicago) Dec. 30, 1897, (2) IV, 382-389. 
B2c $\beta$, Two systems of subgroups of the quaternary abelian group in a general Galois field, L. E. Dickson, Aug. 31, 1903, (2) x, 178184 ; Erratum, 362.

B2cy, The structure of the hypoabelian groups, L. E. Dickson, (Chicago) Apr. 9, 1898, (2) IV, 495-510.

B2d, On the subgroups of order a power of $p$ in the linear homogeneous and fractional groups in the $G F\left[p_{n}\right]$, L. E. Dickson, Feb. 27, 1904, (2) $x, 385-397$.

B2d $\beta$, Note on the special linear homogeneous group, H. TABer, (2) II, 336-339; Correction, (2) III, 121.

B3a, Note on resultants, M. W. HAskell, I, 223-224.

B3a, Reduction of the resultant of a binary quadric and $n$-ic by virtue of its semicombinant property, H. S. WHITE, Aug. 15, 1894, (2) I, $11-15$.

B4,7, The cubic resolvent of a binary quartic derived by invariant definition and process, H. S. WhITE, (Chicago) Jan. 1, 1897, (2) III, 250-253.

B4a, On a definitive property of the covariant, C. J. Keyser, Apr. 29, 1899 , (2) v, 468-469.

B4a, (C4a, (2) IV, 313-322).

B4b, On lists of covariants, E. McClintock, I, 85-91.

B4c, V9, Report on the theory of projective invariants: the chief contributions of a decade, H. S. WHITE, (2) v, 161-175.

B4d, 9d, On a remarkable covariant of a system of quantics, H. B. Newson, Mar. 28, 1896, (2) II, 272-275.

B4d, ( $\mathbf{M}^{2} 1$ d, 3c, (2) v, 282-292; (2) vi, 328-337).

B6a, (M'8g, (2) vII, 392-399; $\mathbf{M}^{2} 9 \mathrm{e}$, (2) vIII, 243-248).

B6c, $\mathbf{M}^{1} 6, \mathbf{M}^{3} 5$, On a certain class of canonical forms, R. A. RoBerts, Dec. 28, 1894, (2) I, 105-111.

B7b, F1, On the connection between binary quartics and elliptic functions, E. Study, (2) I, 6-10.

B12a, ( ( ${ }^{1} 8 \mathrm{~b},(2)$ vI, 163-168).

B12c, (Q4c, (2) I, 33-52; V9, (2) x, 34-39).

B12d, Elementary proof of the quaternion associative principle, A. S. HathaWAY, Aug. 28, 1895, (2) II, 43-45.

B12d, Q2, Quaternions as numbers of four-dimensional space, A. S. Hathaway, (Chicago) Apr. 24, 1897, (2) Iv, 54-57.

B12h, (V, (2) vI, 381-390).

B, Elliott's Algebra of quantics, H. S. White, (2) IV, 545-549. (An introduction to the algebra of quantics, E. B. Elliott, 1895.)

B, I, Muth's Elementartheiler, T. J. I'A. BRoмwICH, (2) vIr, 308-316. ('Theorie und Anwendung der Elementartheiler, P. Muth, 1899.)

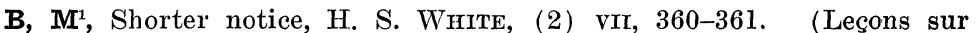
la théorie des formes et la géométrie analytique supérieure, volume 1, H. Andoyer, 1900.) 
B, I, Shorter notice, A. Macfarlane, (2) x, 515. (Conceptos fundamentales de analysis matematica, L. C. Ricart, 1903.)

B, (A, (2) IV, 200-234).

B1, Shorter notice, H. E. Hawkes, (2) Ix, 560-561. (Elemente der Theorie der Determinanten mit vielen Uebungsaufgaben, P. Mansion, 1899.)

B2, I3c, Dickson's Linear groups, G. A. Mrller, (2) IX, 165-172. (Linear groups with an exposition of the Galois field theory, L. E. Dickson, 1901.)

B2c $\gamma$, (D, (2) vI, 78-84).

B2d $\beta$, (G6, (2) IX, 470-492).

B4, (V9, III, 187-190).

B6, 7, 8, Shorter notice, H. S. White, (2) vi, 29-30. (Leçons élémentaires sur la théorie des formes et ses applications géométriques, H. Andoyer, 1898.)

B12, D2, Hayward's Vector algebra, M. Bôcher, (2) I, 111-115. (The algebra of coplanar vectors and trigonometry, R. B. Hayward, 1892.)

B12, Vector analysis, A. ZrweT, (2) vIII, 207-215. (Vector analysis, J. W. Gibbs, edited by E. B. Wilson, 1901.)

B12, Shorter notice, E. B. Wilson, (2) x, 263-266. (Elemente der Vektor-Analysis, A. H. Bucherer, 1903.)

B12a, L18b, Reye's Geometrie der Lage, C. A. ScotT, (2) V, 175-181. (Lectures on the geometry of position, T. Reye, translated and edited by T. F. Holgate, Part 1, 1898.)

B12c, Shorter notice, A. ZIwET, (2) I, 73-75. (Hermann Grassmann: Gesammelte mathematische und physikalische Werke, Band 1, Theil 1: Die Ausdehnungslehre von 1844 und die Geometrische Analyse, F. Engel und E. Study, 1894.)

B12c, O, Shorter notice, E. B. WILson, (2) vII, 231-233. (Application de la méthode vectorielle de Grassmann à la géométrie infinitésimale, H. Fehr, 1899.)

B12d, R, Utility of quaternions in physics, A. S. HathawAY, III, 179185. (Utility of quaternions in physics, A. McAulay, 1893.)

B12d, Macfarlane's Algebra of physics, C. H. Chapman, III, 235-242. (Principles of the algebra of physics, A. Macfarlane, 1891. On the imaginary of algebra, A. Macfarlane, 1892.)

B12d, Quaternions, J. B. SHAw, (2) III, 106-107. (A primer of quaternions, A. S. Hathaway, 1896.)

B12e, McAulay's Octonions, A. S. Hathaway, (2) vi, 74-77. (Octonions, A. McAulay, 1898.)

C.

Principles of differential and integral calculus; analytic applications; quadratures; multiple integrals; functional determinants; differential forms; differential operators.

C1f, Maxima and minima of functions of several variables, J. Pierpont, (2) IV, 535-539.

C2, (D2a, (2) III, 59-86). 
C2d, Note on hyperelliptic integrals, A. S. Chessin, Oct. 30, 1897, (2) IV, 93-96.

C2k, (D3, (2) x, 255-257).

C3, (D1a, (2) viII, 53-63).

C4, (I3, (2) x, 23-30, 30-31).

C4a, Note on the invariants of $n$ points, E. O. LoveTt, Apr. 24, 1897, (2) $1 \mathrm{v}, 58-59$.

C4a, B4a, Some examples of differential invariants, C. L. Bouton, Dec. 29,1897 , (2) IV, 313-322.

C, D, E, O, Picard's Traité d'analyse, T. CraIG, III, 39-65. (Traité d'analyse, E. Picard, 1891-1893.)

C, D, J5, Jordan's Cours d'analyse, J. Hakikness, III, 135-141. (Cours d'analyse de r'École polytechnique, volume 1, C. Jordan, 1893.)

C, D, Picard's Traité d'analyse, M. Bôcher, (2) vIII, 124-128. (Traité d'analyse, volume 1, E. Picard, 1901.

C, A modern English calculus, W. F. OsGood, (2) viıI, 248-257. (An elementary treatise on the calculus, G. A. Gibson, 1901.)

C, Kiepert's Calculus, E. W. DAvis, (2) vIII, 412-418. (Grundriss der Differential- und Integral-Rechnung, L. Kiepert, 1900-1901.)

C, (R, (2) vI, 115-116).

C1, Edwards's Differential calculus, C. A. Scotr, I, 217-223. (An elementary treatise on the differential calculus, J. Edwards, 1892.)

C1,2, Kiepert's Differential and integral calculus, E. B. VAN VLECK, (2) III, 391-399. (Grundriss der Differential- und IntegralRechnung, L. Kiepert, 1895-1896.)

C1, 2, Recent text books of the calculus, T. S. Fiske, (2) IV, 237-238, 278--283. (Easy lessons in the differential calculus, R. A. Proctor, 1894; A primer of the calculus, E. S. Gould, 1896; A brief introduction to the infinitesimal calculus, I. Fisher, 1897. Elements of the differential and integral calculus, W. S. Hall, 1897; Elements of the differential and integral calculus, J. W. Nicholson, 1896; Elements of differential calculus, E. W. Bass, 1896; The calculus for engineers, J. Perry, 1897.)

C1, 2, Shorter notice, J. PJerpont, (2) v, 483-484. (Corso de analyse infinitesimal, F. G. TeIXeIrA, 1892-1896.)

C1, 2, Elements of the calculus, L. E. Dickson, (2) vI, 348-351. (The elements of the differential and integral calculus, J. W. A. Young and C. E. Linebarger, 1900.)

C1, 2, H, A German calculus for engineers, E. R. HEDRICK, (2) Ix, 434442. (Hauptsätze der Differential- und Integral-Rechnung, R. Fricke, 1902.)

C1, 2, Shorter notice, E. B. WrLson, (2) IX, 504-506. (Höhere Analysis für Ingenieure, J. Perry, deutsche Bearbeitung von R. Fricke und F. Sizchting, 1903.)

C1, 2, D, A modern French calculus, W. F. OsGood, (2) Ix, 547-555. (Cours d'analyse mathématique, tome 1, E. Goursat, 1902.) 
C1, 2, Shorter notice, C. M. Mason, (2) x, 511-512. (Elementary calculus, P. F. Smith, 1902-1903.)

C5, H10, 12, The calculus of generalization, E. O. Lovert, (2) vr, 109113. (Calcul de généralisation, G. Oltramare, 1899.)

\section{D.}

General theory of functions and its application to algebraic and circular functions; infinite series and infinite developments including in particular infinite products and continued fractions considered from an algebraic standpoint; Bernoulli's numbers; spherical functions and analogous functions.

D, Some points in the elements of the theory of functions, W. F. OsGood, (2) II, 296-302.

D, J5, Selected topics in the general theory of functions, W. F. OsGood, Aug. 22-27, 1898, (2) v, 59-87.

D1, On linear dependence of functions of one variable, M. BôchER, Oct. 27, 1900, (2) vII, 120-121; Errata, 234.

D1, (H5d $\beta$, ja, (2) IV, 295-313, 365-376 ; (2) v, 22-43; H5j $\alpha$, (2) vII, $333-340)$.

D1a, H4, C3, On Wronskians of functions of a real variable, M. Bôcher, Aug. 20, 1901, (2) vinI, 53-63.

D1a, (H4, (2) vII, 297-299).

D1b, c, B1, On a general formula for the expansion of functions in series, W. H. EchoLs, Jan. 7, 1893, II, 135-144.

D1b, Dini's method of showing the convergence of Fourier's series and of other allied developments, W. B. ForD, Dec. 28, 1900, (2) vII, 227-230.

D1b, (V9, II, 178-184).

D1d, A proof of the theorem $\frac{\partial^{2} u}{\partial x \partial y}=\frac{\partial^{2} u}{\partial y \partial x}$, J. K. Whittemone, Apr. 30, 1898, (2) IV, 389-390.

D1da, H9, Singular points of functions which satisfy partial differential equations of the elliptic type, M. Bôcher, Dec. 30, 1902, (2) $\mathrm{IX}, 455-465$.

D2, Multiplication of series, F. CAJoRI, I, 184-189.

D2a, On the general term in the reversion of series, J. McMaHon, III, $170-172$.

D2a, The multiplication of semi-convergent series, F. CAJoRI, (2) I, 180-183.

D2a, On divergent series, A. S. CHEssin, (2) II, 72-75.

D2a, Additional note on divergent series, A. S. CHEssin, (2) II, 177-179.

D2a, C2, A geometrical method for the treatment of uniform convergence and certain double limits, W. F. OsGood, Aug. 31, 1896, (2) III, 59-86.

D2a, Note on the integration of a uniformly convergent series through an infinite interval, T. S. Fiske, Jan. 30, 1897, (2) III, 223-224.

D2a, $b$, The application of the fundamental laws of algebra to the multiplication of infinite series, F. CAJORI, (2) VIII, 231-236. 
D2a, Series whose product is absolutely convergent, F. CAJORI, (2) IX, 188-194.

D2a, On a test for non-uniform convergence, W. H. Young, Aug. 31, 1903, (2) x, 239-246.

D2aa, Evolution of criteria of convergence, F. CAJORI, II, 1-10.

D2aa, (V8, III, 186-187).

$\mathbf{D} 2 \mathrm{~b}, \mathrm{U3}$, On the convergence of the series used in the subject of perturbations, G. W. Hul, Nov. 30, 1895, (2) II, 93-97.

D3, C2k, Note on Cauchy's integral, O. D. Kellogg, Dec. 28, 1903, (2) $\mathrm{x}, 255-257$.

D3a, Note on monogenic functions of a single variable, T. CraIG, Oct. 7, 1892, III, 78-79.

D3a, On Cauchy's theorem concerning complex integrals, M. BôcHer, (2) II, 146-149.

D4, Note on the sufficient conditions for an analytic function, D. R. Curtiss, Apr. 26, 1902, (2) viII, 329-331.

D4, On a gap in the ordinary presentation of Weierstrass's theory of functions, W. F. Osgood, Dec. 28, 1903, (2) x, 294-301.

D4d, e, J5, Note on the generalization of Poincare and Goursat's proof of a theorem of Weierstrass's, W. F. OsGood, Aug. 19, 1898, (2) v, 14-17.

D4e,5c, Example of a single-valued function with a natural boundary, whose inverse is also single-valued, W. F. Osgood, Apr. 30, 1898, (2) IV, 417-424.

D4e,5c, Supplementary note on a single-valued function with a natural boundary, whose inverse is also single-valued, W. F. OsGood, Aug. 19,1898, (2) $\mathrm{v}, 17-18$.

D5, (V9, (2) I, 165-180).

D6a, A generalization of Appell's factorial functions, E. J. WILCZYNski, Dec. 28, 1898, (2) v, 388-394.

D6ar, (M14a, (2) II, 168-173).

D6b, On the definition of logarithms, M. W. Haskels, II, 164-167.

D6b, Note on the definitions of logarithm and exponential, I. STRINGHAM, II, $168-170$.

D6b, The logarithm as a direct function, E. McClintock, Feb. 28, 1903, (2) IX, 467-469.

D6d, On the introduction of the notion of hyperbolic functions, M. W. Haskei.r, Dec. 28, 1894, (2) I, 155-159.

D6e, Note on the roots of Bessel's functions, M. B. Porter, Feb. 26, 1898, (2) IV, 274-275.

D6e, H5i, An elementary proof that Bessel's functions of the zeroth order have an infinite number of real roots, M. BôcHer, Feb. 25, 1899, (2) $\mathrm{v}, 385-388$.

D6j, (V9, I, 173-184).

D, F, The theory of functions, H. Mascine, III, 155-167. (A treatise on the theory of functions, J. Harkness and F. Morley, 1893.) 
D, The theory of functions, W. F. OsGoon, (2) I, 142-154. (Theory of functions of a complex variable, A. R. Forsyth, 1893.)

D, The algebraic functions and their integrals, W. F. OsGood, (2) II, 317-327. (Thêorie des fonctions algébriques et de leurs intégrales, P. Appell et E. Goursat, 1895.)

D, Burkhardt's Theory of functions, M. Bôcrier, (2) v, 181-185. (Funktionentheoretische Vorlesungen, Erster Teil: Einfiihrung in die Theorie der analytischen Funktionen einer complexen Veränderlichen, H. Burkhardt, 1897.)

D, Burkhardt's Theory of functions, L. E. Dickson, (2) x, 317-321. (Funktionentheoretische Vorlesungen, Band 1, H. Burkhardt, 1903.)

D, The theory of functions, O. BolzA, (2) vi, 63-74. (Introduction to the theory of analytic functions, J. Harkness and F. Morley, 1898.)

$\mathbf{D}, \mathbf{B} 2 \mathbf{c} \gamma, \mathbf{H}, \mathbf{T} 4$, Theses in mathematics at the University of Paris, E. O. LovETT, (2) VI, 78-84. (Sur quelques points de la théorie des fonctions, L. Desaint, 1897; Sur une classe particulière de groupes hyperabéliens, H. Bourget, 1898; Sur l'intégration des équations de la chaleur, E. LeRoy, 1898; Les équations différentielles linéaires et la théorie des groupes, F. Marotte, 1898; Essai sur une théorie générale de l'intégration et sur la classification des transcendantes, J. Drach, 1898.)

D, H, O, Méray's Infinitesimal analysis, E. O. Lovetr, (2) vI, 204-212. (Leçons nouvelles sur l'analyse infinitésimale et ses applications géométriques, C. Méray, 1894-1898.)

D, F, H, Shorter notice, H. S. WhITE, (2) vII, 316-318. (Kurzgefasste Vorlesungen über verschiedene Gebiete der höheren Mathematik, mit Berücksichtigung der Anwendungen, R. Fricke, 1900.)

D, (C, III, 39-65, 135-141; (2) vIII, 124-128; C1, 2, (2) IX, 547-555).

D1, The theory of functions of a real variable, J. HARKNESS, II, 71-76. (U. Dini, Grundlagen für eine Theorie der Funktionen einer veränderlichen reellen Grösse, deutsch bearbeitet von J. Lüroth und A. Schepp, 1892.)

D1b, Shorter notice, W. B. Ford, (2) vI, 407. (Vorlesungen über Kreisund Kugel-Funktionen-Reihen, J. Frischauf, 1897.)

D1b, (H10, III, 245-248).

D2, Shorter notice, J. Harkness, (2) IV, 277-278. (Introduction to infinite series, W. F. Osgoon.)

D2, E1, Shorter notice, M. B. Ponter, (2) IX, 502-504. (Théorie élémentaire des séries, M. Godefroy, 1903; La fonction gamma, M. Godefroy, 1902.)

D2, 6, E, F, Whittaker's Modern analysis, M. Bôcher, (2) x, 351-354. (A course of modern analysis, E. T. Whittaker, 1902.)

D2, (B12, (2) I, 111-115).

D2b, Memoirs on infinite series, L. L. Conant, III, 223-224. (Memoirs on infinite series, published by the Tokio Mathematical and Physical Society, 1891.)

D4c, Shorter notice, E. B. WILson, (2) IX, 506-507. (Leçons sur les fonctions méromorphes, $\mathrm{E}$. Borel, recueillies et rédigées par L. Zoretti, 1903.) 
D5b, (G3, (2) v, 308-312.)

D6, Shorter notice, F. Morley, (2) III, 225. (Ebene und räumliche Geometrie des Masses, L. Huebner, 1895.)

D6, Picard's Algebraic functions of two variables, A. BERRY, (2) v, 438-451. (Théorie des fonctions algébriques de deux variables indépendantes, E. Picard et G. Simart, Tome 1, 1897.)

D6e, S, T, Bessel functions, M. Bôcher, (2) II, 255-265. (A treatise on Bessel functions and their applications to physics, A. Gray and G. B. Mathews, 1895.)

D6e, H5i, Bessel's functions, V. SNyder, (2) V, 253-258 ; (2) vII, 354358. (Einleitung in die Theorie der Bessel'schen Funktionen, J. H. Graf und E. Gubler, Heft 1, 1898, Heft 2, 1900.)

D6f, (H10, III, 245-248).

E.

Definite integrals, particularly eulerian integrals.

E5, The value of $\int_{0}^{\pi / 2}(\log 2 \cos \phi)^{m} \phi^{n} d \phi$, F. MorLey, Apr. 29, 1899, (2) vII, 390-392.

E, F, G, Jordan's Cours d'analyse, J. Harkness, (2) I, 248-252. (Cours d'analyse de l'Ecole Polytechnique, C. Jordan, tome 2, Calcul intégral, 1894.)

F, (C, III, 39-65; D2, 6, (2) x, 351-354).

E1, (D2, (2) IX, 502-504).

F.

Elliptic functions with their applications.

F, On elliptic functions, J. Pienpont, Apr. 29, 1899, (2) v, 490-492.

F1, On the doubly intinite products, T. S. Fiske, Nov. 7, 1890, I, 61-66.

F1, Note on a memoir in Smith's collected papers, A. Cayler, (2) I, 94-96.

F1, (B7b, (2) I, 6-10).

$\mathbf{F} 4 \mathrm{a} \beta$, On a generalization of Weierstrass's equation with three terms, F. MoRLEY, Aug. 27, 1895, (2) II, 21-22.

F5d, A4d, On modular equations, J. Pienpont, Mar. 27, 1897, (2) III, 279-292.

F8f, $\mathbf{M}^{2} 4 \mathbf{k}, \mathbf{N}^{1} 1$, Concerning the elliptic $8\left(g_{2}, g_{3}, z\right)$-functions as coordinates in a line complex, and certain related theorems, H. F. STECKER, Oct. 26, 1901, (2) VIII, 148-153.

F8f, ( $\mathbf{M}^{2} 4 \mathbf{i} \delta$, (2) II, 19-21).

F, The elliptic functions, J. HARkNess, II, 151-157. (The applications of elliptic functions, A. G. Greenhill, 1892.)

F, Burkhardt's Elliptic functions, J. PIERPON'T, (2) VI, 452-463. (Funktionentheoretische Vorlesungen, H. Burkhardt, Teil 2: Elliptische Functionen, 1899.)

F, (D, III, 155-167; (2) vir, 316-318; D2, 6, (2) X, 351-354; E, (2) I, 248-252). 
F7, Klein's Modular functions, F. N. Cole, I, 105-120. (Vorlesungen über die Theorie der elliptischen Modulfunktionen, F. Klein, ausgearbeitet und vervollständigt von $\mathrm{R}$. Fricke, 1890.)

G.

Hyperelliptic, abelian, and fuchsian functions.

G3, On a theorem concerring $p$-rowed characteristics with denominator 2, E. H. Moore, (2) 1, 252-255.

G6aa, (H, II, 119-134).

G, (E, (2) I, 248-252).

G3, D5b, Stahl's Abelian functions, V. SNyder, (2) v, 308-312. (Theorie der Abel'schen Funktionen, H. Stahl, 1896.)

G6, B2d $\beta$, The theory of automorphic functions, J. I. Hutchinson, (2) IX, 470-492. (Vorlesungen uiber die Theorie der automorphen Functionen, R. Fricke und F. Klein, 1897-1901.)

H.

Differential equations; partial differential equations; functional equations; equations of finite differences; recurrent series.

H, G6aa, V9, Some of the developments in the theory of ordinary differential equations between 1878 and 1893, T. CraIG, Feb. 4, 1893, II, 119-134.

H, (A, (2) vIII, 437-479; U3, 4, 5, (2) vIII, 103-113).

H1a, Picard's demonstration of the general theorem upon the existence of integrals of ordinary differential equations, translated by T. S. Fiske, I, 12-16.

H1da, (J4f, (2) II, 221-233; R3a, (2) IX, 308-328).

H1h, (L'17, (2) II, 1l-19).

H2a, Note on integrating factors, P. SAUREL, Feb. 26, 1898, (2) IV, $329-331$.

H2c $\gamma,(\mathrm{O} 2 \mathrm{~m}$, (2) $\mathrm{x}, 341-346,405)$.

H4, D1a, Green's functions in space of one dimension, M. Bôcher, Feb. 23, 1901, (2) VII, 297-299.

H4, On integrability by quadratures, S. Epsteen, Sept. 3, 1902, (2) Ix, 152-154.

H4, Note on the $p$-discriminant of ordinary linear differential equations, A. Емсн, Aug. 31, 1903, (2) x, 137-139.

H4, (D1a, (2) VIII, 53-63).

H4a, b, Some applications of Green's theorem in one dimension, $O$. DunKeL, Feb, 22, 1902, (2) viIr, 288-292.

H4e, J4aa, Proof that the group of an irreducible linear differential equation is transitive, S. Epsteen, Dec. 28, 1901, (2) vIII, 239-241.

H5, On singular points of linear differential equations with real coefficients, M. BôcHER, Oct. 29, 1898, (2) v, 275-281.

$\operatorname{H} 5 \mathrm{~d} \beta, \mathrm{j} \alpha, \mathrm{D} 1$, The theorems of oscillation of Sturm and Klein, M. BôcHER: First paper, Dec. 29, 1897, (2) IV, 295-313; Second paper, 
Feb. 26, 1898, (2) Iv, 365-376; Third paper, Aug. 19, 1898, (2) v, 22-43.

H5f, On the number of roots of the hypergeometric series between zero and one, M. B. Porter Mar. 27, 1897, (2) III, 274-278.

H5f, Note on the enumeration of the roots of the hypergeometric series between zero and one, M. B. PonTer, Feb. 24, 1900, (2) vi, 280-282.

H5f, An expression of certain known functions as generalized hypergeometric functions, E. T. WHITTAKER, Aug. 31, 1903, (2) x, 125134.

H5g, A3j, The roots of polynomials which satisfy certain linear differential equations of the second order, M. Bôcher, Dec. 29, 1897, (2) IV, 256-258.

H5g, A3j, On the polynomials of Stieltjes, E. B. VAN VLECK, Apr. 30, 1898, (2) IV, 426-438.

H5i, On certain methods of Sturm and their application to the roots of Bessel's functions, M. Bôcher, Feb. 27, 1897, (2) III, 205-213.

H5i, (D6e, (2) v, 385-388; T2, (2) II, 173-177).

H5ia, (V8, II, 107-109; X2, (2) III, 153-155).

H5ja, Some theorems concerning linear differential equations of the second order, M. Bôcher, Feb. 24, 1900, (2) vI, 279-280.

H5ja, D1, Non-oscillatory linear differential equations of the second order, M. BôcHer, Feb. 23, 1901, (2) vII, 333-340.

H9, (D1da, (2) IX, 455-465).

H10da, Note on Poisson's integral, M. Bôcher, Apr. 30, 1898, (2) IV, 424-426.

H12, ( V, (2) vI, 381-390).

$\mathbf{H 1 2 b}$, J4f, On linear homogeneous difference equations and continuous groups, S. Epsteen, (Chicago) Apr. 2, 1904, (2) x, 499-504.

H, Shorter notice, H. B. Fine, (2) IV, 275-276. (Introductory course in differential equations for students in classical and engineering colleges, D. A. Murray, 1897.)

H, Page's Differential equations, E. O. Lovetr, (2) Iv, 349-353; Note, L. E. Dickson, (2) v, 451-455. (Ordinary differential equations, J. M. Page, 1897.)

H, S, T, Riemann-Weber : Partial differential equations of mathematical physics, J. S. Ames, (2) vir, 81-85. (Die partiellen Differentialgleichungen der mathematischen Physik, nach Riemann's Vorlesungen in vierter Auflage neu bearbeitet von $H$. Weber, 1900, 1901.)

H, Shorter notice, M. Bôcher, (2) vIII, 168-169. (Einführung in die Theorie der Differentialgleichungen mit einer unabhängigen Variablen, L. Schlesinger, 1900.)

H, Shorter notice, E. R. HEDRICK, (2) IX, 126-127. (Zur Integration partieller Differentialgleichungen, K. Boehm, 1900.)

H, Forsyth's Differential equations, E. J. WilczynskI, (2) x, 86-93. ('Theory of differential equations, volumes 2-4, A. R. Forsyth.) 
H, (C1, 2, (2) Ix, 434-442; D, (2) VI, 78-84, 204-212; (2) vII, 316318 ; J4f, (2) IV, 155-167).

H1d $\alpha$, (J4, II, 61-71).

H3b, ( $R$, (2) II, 164-168).

H4, 5, Shorter notice, J. C. FIELDS, I, 48-54. (A treatise on linear differential equations, volume 1, T. CRAIG, 1889.)

H4, 5, Linear differential equations, M. Bôcher, (2) III, 86-92. (Einleitung in die Theorie der linearen Differentialgleichungen mit einer unabhängigen Variablen, L. Heffter, 1894.)

H4,5, Linear differential equations, M. BôCHER, (2) III, 146-153. (Handbuch der Theorie der linearen Differentialgleichungen, Band I, L. Schlesinger, 1895.)

H5i, (D6e, (2) v, 253-258; (2) vII, 354-358).

H8, Shorter notice, E. O. Lovert, (2) vi, 31-32. (Leçons sur la theorie analytique des équations aux dérivées partielles du premier ordre, E. Delassus, 1897.)

H9, 10, Goursat's Partial differential equations, E. O. LoveTr, (2) IV, 452-487. (Leçons sur l'intégration des équations aux dérivées partielles du second ordre à deux variables independantes, E. Goursat, 1896, 1898.)

H10, D1b, 6f, Fourier's series and harmonic functions, A. G. WebsteR, III, 245-248. (An elementary treatise on Fourier's series and spherical, cylindrical, and ellipsoidal harmonics, W. E. Byerly, 1893.)

H10, 12, (C5, (2) vI, 109-113).

H12, Calculus of finite differences, D. A. Murray, (2) v, 313-316. (Differenzenrechnung, A. A. Markoff, deutsche Uebersetzung von T. Friesendorff and E. Prümm, 1896.)

\section{I.}

Arithmetic and theory of numbers; indeterminate analysis; arithmetical theory of forms and of continued fractions; division of the circle; complex, ideal, and transcendental numbers.

I, (A, (2) vIIr, 437-479).

I1, Octonary numeration, W. W. JoHnson, I, 1-6.

I1, V9, Note on Hamilton's determination of irrational numbers, H. E. Hawkes, Feb. 23, 1901, (2) VII, 306-307.

I1, J5, The Heine-Borel theorem, O. Veblen, (2) x, 436-439.

I1, (V3, (2) IV, 530-535).

I2b $a, 13 c$, On the factoring of large numbers, F. N. Cole, Oct. 31, 1903, (2) $\mathrm{x}, 134-137$; Errata, 362 .

I3, A4, C4, On linear differential congruences, S. Epsteen, Apr. 25, 1903, (2) $\mathrm{x}, 23-30$.

I3, A4, C4, Fields whose elements are linear differential expressions, L. E. Dickson, Apr. 25, 1903, (2) x, 30-31.

I3, 22, On the congruence $x \phi(P) \equiv 1, \bmod . P_{n}$, J. Westlund, Aug. 31, $1903,(2) \times, 78-80$. 
I3b, A two-fold generalization of Fermat's theorem, E. H. Moore, Feb. 29, 1896, (2) II, 189-199.

I3c, Higher irreducible congruences, L. E. DICkson, (2) III, 381-389.

I3c, Proof of the existence of the Galois field of order $p^{r}$ for every integer $r$ and prime number $p$, L. E. Dickson, Dec. 28, 1899, (2) vI, 203204.

I3c, (J4a, III, 73-78).

I7a, (J4ba, (2) vIr, 350-354).

I12, X.2, Errors in Legendre's tables of linear divisors, D. N. LEHMER, (2) VIII, 401-402.

I13, Errata in Gauss's Tafel der Anzahl der Classen binärer quadratischer Formen, A. M. NASH, communicated by E. B. ElliotT, (2) $\mathrm{Ix}, 466-467$.

I17, Note on an error in Ball's History of mathematics, A. MarTin, II, $10-11$.

I22, The decomposition of modular systems of rank $n$ in $n$ variables, $\mathrm{E}$. H. Moone, (Chicago) Apr. 24, 1897, (2) III, 372-380.

I22c, Weierstrass and Dedekind on general complex numbers, C. $H$. Chapman, I, 150-15̌6.

I24, Transcendental numbers, H. WeBER, translation by W. W. BemaN of Lehrbuch der Algebra, volume 2, chapter 25, (2) III, 174-195.

I, Q, R, Mathematical recreations, J. E. OLIver, II, 37-46. (Mathematical recreations and problems of past and present times, W. W. R. Ball, 1892.)

I, Bachmann's 'Theory of numbers, J. W. A. Young, III, 215-222. (Die Elemente der Zahlentheorie, P. Bachmann, 1892.)

I, A4, J4a, Theory of numbers and of equations, J. W. A. Young, (2) III, 97-105. (Introduction à l'étude de la théorie des nombres et de l'algèbre supérieure, E. Borel et J. Drach, 1895.)

I, Shorter notice, A. B. Frizexl, (2) viII, 169-171. (Introduction to higher algebra, J. N. Hatzidakis, 1898.)

I, Shorter notice, L. E. DICkson, (2) viII, 257-259. (Eléments de la théorie des nombres, E. Cahen, 1900.)

I, Kronecker's Lectures on the theory of numbers, G. A. Miller, (2) vIII, 303-307. (Vorlesungen ïber Mathematik, von L. Kronecker, Theil 2, Band 1: Vorlesungen iiber Zahlentheorie, bearbeitet und herausgegeben von $\mathrm{K}$. Hensel.)

I, On a new edition of Stolz's Allgemeine Arithmetik, with an account of Peano's definition of number, E. V. Huntington, (2) Ix, 40-46. ('Theoretische Arithmetik, O. Stolz und J. A. Gmeiner, Abtheilung 1: Die Lehre von den rationalen Zahlen, 1901.)

I, Shorter notice, L. E. Dickson, (2) Ix, 555-556. (Niedere Zahlentheorie, Erster Theil, P. Bachmann, 1902.)

I, (B, (2) vII, 308-316; (2) $\mathrm{x}, 515$ ).

I1, Shorter notice, L. E. Dickson, (2) vIII, 259-260. (Essays on the theory of numbers: I, Continuity and irrational numbers. II, The 
nature and meaning of numbers, R. Dedekind, translated by W. W. Beman, 1901.)

I2, 3, Shorter notice, D. N. LeHmer, (2) $\mathrm{x}, 412-413$. (Elements of the theory of integers, J. Bowden, 1903.)

12a, The theory of numbers, J. dE Perott, (2) I, 217-232. (Sur la théorie des nombres, T. J. Stieltjes, 1895.)

I3c, (B2, (2) IX, 165-172).

I4a, Q2, Shorter notice, E. O. Lovetr, (2) vI, 30-31. (Sur les lois de réciprocité, $\mathrm{X}$. Stouff, 1898.)

I24, (K21b, c, d, (2) II, 157-164).

I25b, X2, Triangular numbers, E. L. Stabler, (2) III, 399-401. (Projet de table de triangulaires de 1 a 100000, etc., A. Árnaudeau, 1896.)

\section{J.}

Combinatory analysis; calculus of probabilities; calculus of variations; general theory of transformation groups [excepting Galois groups (A), groups of linear substitutions (B), and groups of geometric transformations (P) ]; Cantor's theory of

J, (A, (2) virI, 437-479).

$\mathbf{J} 1, \mathbf{V} 1$, On exact analysis as the basis of language, A. Macfarlane, Mar. 5, 1892, I, 189-193.

J1,4, Concerning regular triple systems, E. H. Moone, Aug. 17, 1897, (2) $1 v, 11-16$.

J1, A generating function for the number of permutations with an assigned number of sequences, F. MorLey, May 29, 1897, (2) IV, 23-28.

J1a, Gergonne's pile problem, L. E. Dickson, (2) I, 184-186.

J1a , (B1, III, 142-148).

J2e, f, A problem in least squares, M. Merriman, I, 39-42.

J2e, On Peters's formula for probable error, W. W. Johnson, June 4, 1892, II, 57-61.

J2g, Moral values, R. Henderson, Oct. 26, 1895, (2) II, 46-51.

J3, Some instructive examples in the calculus of variations, O. BolzA, Sept. 2, 1902, (2) $\mathrm{Ix}, 1-10$.

J3, On the sufficient conditions in the calculus of variations, E. R. HEDRICK, Dec. 28, 1901, (2) Ix, 11-24.

J3, Supplementary note on the calculus of variations, E. R. HEDRICK, (2) Ix, 245-247.

J4, On several theorems of operation groups, G. A. MILlER, (2) III, 111-116.

J4, P, Indirect circular transformations and mixed groups, H. B. Newson, Feb. 23, 1901, (2) vII, 259-266.

J4, (B2, (2) IV, 107-121; V1, II, 215-249).

$\mathrm{J} 4 \mathrm{a}$, Note on the substitution groups of six, seven, and eight letters, F. N. CoLE, II, 184-190. 
J4a, The transitive substitution groups of nine letters, F. N. CoLE, II, 250-258.

J4a, I3c, A doubly-infinite system of simple groups, E. H. Moore, III, 73-78.

J4a, Note on substitution groups of eight letters, G. A. MILLER, III, 168-169.

J4a, Note on the substitution groups of eight and nine letters, G. A. Miller, III, 242-245.

$\mathbf{J} 4 \mathrm{a}$, The group of holoedric transformation into itself of a given group, E. H. Moore, Nov. 24, 1894, (2) I, 61-66.

J4a, On the non-primitive substitution groups of degree ten, G. A. MiILER, (2) I, 67-72.

J4a, An instance where a well-known test to prove the simplicity of a simple group is insufficient, G. A. Miller, (2) I, 124-125.

J4a, Note on Hölder's theorem concerning the constancy of factor groups, G. L. Brown, (2) I, 232-234.

J4a, Note on the transitive substitution groups of degree twelve, G. A. Miller, (2) I, 255-258.

$\mathrm{J} 4 \mathrm{a}$, A simple proof of a fundamental theorem of substitution groups, and several applications of the theorem, G. A. MIILLER, (2) II, 75-77.

$\mathrm{J} 4 \mathrm{a}$, On the lists of all the substitution groups that can be formed with a given number of elements, G. A. MrLIER, (2) II, 138-145.

$\mathbf{J} 4$ a, The substitution groups whose order is the product of two unequal prime numbers, G. A. Miller, (2) II, 332-336.

$\mathbf{J} 4 \mathbf{a}$, On the transitive substitution groups whose orders are the products of three prime numbers, G. A. Mrller, Jan. 30, 1897, (2) III, 213-222.

J4a, On the commutator groups, G. A. Mrller, Aug. 17, 1897, (2) IV, 135-139.

J4a, On an extension of Sylow's theorem, G. A. Mrller, Feb. 26, 1898, (2) IV, 323-327.

J4a, On the Hamilton groups, G. A. MrLler, Apr. 30, 1898, (2) IV, 510-515.

J4a, e, On the groups generated by two operators, G. A. Mrrcer, Apr. 27, 1901, (2) vII, 424-426.

J4a, Simplified definition of a group, E. V. Huntington, Feb. 22, 1902, (2) VIII, 296-300.

J4a, A second definition of a group, E. V. Huntington, Apr. 26, 1902, (2) virr, 388-391.

J4a, (B2c, (2) II, 33-43).

J4aa, On the limit of transitivity of the multiply transitive substitution groups that do not contain the alternating group, G. A. Mrller, Dec. 29, 1897, (2) IV, 140-143.

J4aa, (H4e, (2) virI, 239-241).

$\mathbf{J} 4 \mathbf{b} a$, On the simple isomorphisms of a Hamiltonian group to itself, G. A. Miller, Aug. 20, 1898, (2) v, 292-296. 
J4ba, Note on the group of isomorphisms, G. A. Mrller, Feb. 24, 1900, (2) VI, 337-339.

J4ba, I7a, On holomorphisms and primitive roots, G. A. Mrller, Feb. 23, 1901, (2) vII, 350-354.

$\mathbf{J} 4 \mathbf{b} a$, Upon the non-isomorphism of two simple groups of order $8 ! / 2$, I. M. Schottenfels, Aug. 20, 1901, (2) virt, 25-26.

$\mathbf{J 4 d}$, Report on recent progress in the theory of the groups of a finite order, G. A. MiLler, (2) v, 227-249.

J4d, The known finite simple groups, L. E. Dickson, Apr. 29, 1899, (2) $\mathrm{v}, 470-475$.

J4d, On groups of order $8 ! / 2$, I. M. SchotTenfeLs, June 29, 1900, (2) vi, 440-443.

$\mathbf{J} 4 \mathrm{~d}$, On the abelian groups which are conformal with non-abelian groups, G. A. MILLER, Oct. 26, 1901, (2) vIII, 154-156.

$\mathbf{J} 4 \mathrm{~d}$, Concerning the class of a group of order $p^{m}$ that contains an operator of order $p^{m-2}$ or $p^{m-3}, p$ being a prime, W. B. Fire, Dec. 28, 1901, (2) vIII, 236-239.

$\mathbf{J} 4 \mathrm{~d}$, Determination of all the groups of order $p^{m}, p$ being any prime, which contain the abelian group of order $p^{m-1}$ and of type $(1,1,1, \cdots)$, G. A. Miller, (San Francisco) May 3, 1902, (2) vIII, 391-394.

$\mathbf{J} 4 d$, Second report on recent progress in the theory of groups of finite order, G. A. MILLER, (2) IX, 106-123.

J4d, Concerning the commutator subgroups of groups whose orders are powers of primes, W. B. Fite, Sept. 2, 1902, (2) IX, 139-141.

$\mathbf{J} 4 d$, Three sets of generational relations defining the abstract simple group of order 504, L. E. Dickson, Oct. 25, 1902, (2) IX, 194-204.

J4d, Generational relations defining the abstract simple group of order 660, L. E. Dickson, Oct. 25, 1902, (2) Ix, 204-206.

J4d, The abstract group $G$ simply isomorphic with the alternating group on six letters, L. E. Dickson, Dec. 29, 1902, (2) Ix, 303-306.

J4d, A fundamental theorem with respect to transitive substitution groups, G. A. Miller, Feb. 28, 1903, (2) Ix, 543-544.

J4d, On some properties of groups whose orders are powers of a prime, W. B. Fite, Dec. 28, 1903, (2) x, 346-350.

J4e, f, Systems of continuous and discontinuous simple groups, L. E. Dickson, Apr. 24, 1897, (2) mir, 265-273.

J4e, Note on the simply transitive primitive groups, G. A. MILLER, Oct. 28,1899 , (2) vi, 103-104.

J4e, On the commutators of a given group, G. A. Miller, (2) vI, 105109.

$J 4 e, f$, On the singular transformations of groups generated by infinitesimal transformations, H. TABER, Dec. 28 , 1899, (2) VI, 199203.

J4e, K14g, Report on the groups of an infinite order, G. A. Miller, (2) VII, 121-130.

J4e, V1, Some groups in logic, E. W. DAvis, (Chicago) Jan. 2, 1903, (2) IX, 346-348. 
J4f, H1da, On certain subgroups of the general projective group, $H$. TABER, Jan. 25, 1896, (2) II, 221-233; Erratum, 346.

J4f, Note on the fundamental theorems of Lie's theory of continuous groups, E. O. LoveTT, Oct. 30, 1897, (2) IV, 59-63.

J4f, Note on the theory of continuous groups, J. E. CAMPBELL, (2) IV, 407-408.

J4f, P1, Note on the infinitesimal projective transformation, E. O. LoveTT, Apr. 30, 1898, (2) IV, 515-519.

J4f, $\mathbf{I}^{121 a} \beta$, Infinitesimal transformations of concentric conics, E. $O$. LovetT, Apr. 30, 1898, (2) IV, 520-524.

J4f, B2c, P4b, Concerning real and complex continuous groups, L. E. Dickson, Feb. 23, 1901, (2) vII, 340-350.

J4f, The infinitesimal generators of certain parameter groups, S. E. Slocum, Oct. 26, 1901, (2) vIII, 156-168.

J4f, Note on the transformation of a group into its canonical form; S. E. Srocum, Dec. 28, 1901, (2) viri, 280-288.

J4f, The infinitesimal generators of parameter groups, T. J. I'A. BRoMWICH, Apr. 26, 1902, (2) viII, 375-386.

J4f, (A4d, (2) viII, 63-70; B2, (2) v, 120-135; H12b, (2) X, 499504; P1, (2) vI, 431-439; P6, (2) IV, 97-107, (2) X, 191-193; R3a, (2) IX, 308-328).

J5, Theorems concerning positive definitions of finite assemblage and infinite assemblage, C. J. KeYsER, Dec. 28, 1900, (2) vII, 218-226.

J5, (D, (2) V, 59-87; D4d, e, (2) v, 14-17; I1, (2) X, 436-439; Q1a, (2) IV, 443-448; V1, (2) IX, 424-434).

J2, Shorter notice, E. W. Davis, I, 16-25. (Calcul des probabilités, J. Bertrand, 1889.)

J2, Shorter notice, E. KAsNer, (2) Ix, 215-217. (Probabilités et moyennes géométriques, E. Czuber, traduit par H. Schuermans, 1902 ).

J2e, The adjustment and comparison of observations, M. MERriman, II, 162-163. (Lehrbuch der Ausgleichsrechnung nach der Methode der kleinsten Quadrate, K. J. Bobek, 1891; the theory of errors and method of least squares, W. W. Johnson, 1892.)

J2f, Mathematical problems, E. L. Stabler, I, 123-124. (Solution of questions in the theory of probability and averages, G. B. M. Zerr.)

J2g, The application of mathematics to the theory of economics, T. S. FISKE, II, 204-211. (Mathematical investigations in the theory of value and prices, I. Fisher, 1892.)

J2g, Shorter notice, W. B. BAILEY, (2) v, 488 . (Politische Arithmetik oder die Arithmetik des täglichen Lebens, M. Cantor, 1898.)

J2g, Shorter notice, J. M. GaInes, (2) v, 488-489. (Introduzione alla economia matematica, F. Virgilii and C. Garibaldi, 1899.)

J2g, Shorter notice, J. M. GaInes, (2) Ix, 127-128. (The measurement of general exchange value, C. M. Walsh, 1901.)

J2g, Shorter notice, J. M. Gaines, (2) Ix, 383 . (Net premiums and reserves on joint life policies, A. Hunter, 1902.) 
J3, Pascal's Calculus of variations, J. K. WhitTemone, (2) vI, 352-354. (Die Variationsrechnung, E. Pascal, deutsch von A. Schepp, 1899.)

J4, H1da, The theory of transformation groups, C. H. CHAPMAN, II, 61-71. (Theorie der Transformationsgruppen, Erster Abschnitt, unter Mitwirkung von F. Engel bearbeitet von S. Lie, 1888.)

J4, Burnside's Theory of groups, G. A. Miller, (2) V, 249-251, (2) VI, 390-398. (Theory of groups of a finite order, W. Burnside, 1897.)

J4, V9, Shorter notice, G. A. Mrller, (2) Ix, 557-558. (The constructive development of group theory, with a bibliography, B. S. Easton, 1902.)

J4, (A, (2) IV, 200-234).

J4a, b, c, A4, The theory of substitutions, O. BoLzA, II, 83-106. (The theory of substitutions and its applications to algebra, E. Netto, translated by F. N. Cole, 1892.)

J4a, (I, (2) III, 97-105).

J4d, Shorter notice, B. S. EAston, (2) IX, 559-560. (Enumération des groups d'opérations d'ordre donné, R. Le Vavasseur.)

J4f, Continuous groups, J. M. Brooks, (2) I, 241-248. (Sophus Lie: Vorlesungen über continuierliche Gruppen mit geometrischen und anderen Anwendungen, bearbeitet und herausgegeben von $G$. Scheffers, 1893.)

J4f, H, Lie's Differential equations, E. O. LoveTr, (2) IV, 155-167. (Sophus Lie: Vorlesungen über Differentialgleichungen mit bekannten infinitesimalen Transformationen, bearbeitet und heraus gegeben von G. Scheffers, 1891.)

J4f, (P6e, (2) III, 321-350).

J5, (C, III, 135-141).

K.

Elementary geometry and trigonometry (theory of figures formed from straight lines, planes, circles, and spheres) ; geometry of point, line, plane, circle, and sphere; descriptive geometry; perspective.

K6b, (P4b, (2) v, 143-150).

K7, Q4a, Apolar triangles on a conic, F. MonLEy, Jan. 26, 1895, (2) I, 116-124.

$\mathbf{K} 9 \mathrm{~b}$, On the number of inscriptible regular polygons, L. E. Dickson, III, 123-125.

$\mathbf{K} 9 \mathrm{~b}$, On an undemonstrated theorem of the Disquisitiones arithmeticae, J. Pierpon's, (2) il, 77-83.

K9d, Note on the theory of three similar figures, F. MoRLEY, (2) I, 235-237.

K11e, A geometrical locus connected with a system of coaxial circles, T. F. Holgate, Aug. 16, 1897, (2) IV, 63-67.

K11e, A second locus connected with a system of coaxial circles, $\mathrm{T}$. F. Holgate, Aug. 19, 1898, (2) v, 135-143.

K14g, ( J4e, (2) vII, 121-130).

K20f, Note on Napier's rules of circular parts, E. O. LoveTt, (2) IV, 552-554. 
$\mathbf{K} 21 \mathrm{a} \delta, \mathbf{b}, \mathbf{d}$, Note on Mr. George Peirce's approximate construction for $\pi$, E. LemoIne, Aug. 20, 1901, (2) vin, 137-148.

K21d, A curious approximate construction for $\pi$, G. PEIRCE, Apr. 27, 1901, (2) vII, 426-427.

K, Introductory modern geometry, C. A. ScotT, II, 175-178. (Introductory modern geometry of point, ray, and circle, W. B. Smith, 1893 ).

K, P, Lachlan's Modern pure geometry, F. MoRLey, III, 33-36. (An elementary treatise on modern pure geometry, R. Lachlan, 1893.)

$\mathbf{K}$, Recent text books of geometry, A. S. Hatiraway, (2) III, 108-110. (Elements of geometry, G. C. Edwards, 1895; Plane and solid geometry, W. W. Beman and D. E. Smith, 1895; Plane and solid geometry, C. A. Van Velzer and G. C. Shutts, 1894.)

K, Two books on elementary geometry, I. MADDIson, (2) III, 253-255. (Elements of geometry, A. W. Phillips and I. Fisher, 1896 ; Elementary solid geometry and mensuration, H. D. Thompson, 1896.)

K, Shorter notice, C. A. Scotт, (2) IV, 167-168. (Famous problems of elementary geometry, translation of F. Klein's Vorträge über ausgewählte Fragen der Elementargeometrie, W. W. Beman and D. E. Smith, 1897.)

K, Hadamard's Geometry, F. MorLey, (2) IV, 550-551. (Leçons de géométrie élémentaire, J. Hadamard, 1898.)

K, Some recent German text books in geometry, P. F. SMITH, (2) Ix, 268-271. (Lehrbuch der Elementargeometrie, Teil I: Planimetrie, E. Glinzer, 1899; Grundriss der Geometrie, I: Planimetrie, J. H. Kühl, 1900; Lehrbuch der Stereometrie, P. Sauerbeck, 1900; Die Elemente der analytischen Geometrie, Teil II: Die analytische Geometrie des Raumes, F. Rudio, 1901.)

K, Q1a, Experimental and theoretical geometry, R. E. MorItz, (2) x, 504-510. (Experimental and theoretical course of geometry, A. T. Warren, 1903.)

K, Shorter notice, A. S. Gale, (2) x, 514-515. (Aufgaben aus der niederen Geometrie, I. Alexandroff, 1903.)

K, (V1a, I, 6-12; V3b, (2) vIII, 216-220, 479-481).

K6, A French analytical geometry, C. H. Chapman, I, 92-95. (Leçons de géométrie analytique, Briot et Bouquet, 1890.)

$\mathbf{K} 6,7, \mathbf{P}$, Modern methods of analytical geometry, F. N. CoLE, (2) II, 265-271. (An introductory account of certain modern ideas and methods in plane analytical geometry, C. A. Scott, 1894.)

Ir6, Shorter notice, T. S. FISkE, (2) III, 256. (Briot and Bouquet's Elements of analytical geometry of two dimensions, translated by J. H. Boyd, 1896.)

K6, L, Shorter notice, M. Bôcher, (2) III, 351-352. (Plane and solid analytic geometry, F. H. Bailey and F. S. Woods, 1897.)

KK6, Shorter notice, I. Maddison, (2) IV, 234-235. (Analytic geometry for technical schools and colleges, P. A. Lambert, 1897.)

K6, 7, Analytic projective geometry, E. B. WILson, (2) IX, 369-376. (Lehrbuch der analytischen Geometrie in homogenen Koordinaten, W. Killing, 1900, 1901.) 
K7, P, Shorter notice, F. MonLex, (2) vi, 254-255. (Premiers principes de géométrie moderne, E. Duporcq, 1899.)

K7, I ${ }^{1}, \mathbf{P}$, Shorter notice, H. S. WhITE, (2) vII, 318-319. (Ebene Geometrie der Lage, R. Böger, 1900.)

K7, $\mathbf{L}^{1}$, Enriques's Projective geometry, V. SNyder, (2) x, 355-358. (Vorlesungen über projective Geometrie, F. Enriques, deutsche Ausgabe von H. Fleischer, 1903.)

K20, (V, (2) VI, 404-405; (2) x, 153-157).

$\mathbf{K} 21 \mathrm{~b}, \mathrm{c}, \boldsymbol{d}$, I24, The three great problems of antiquity considered in the light of modern mathematical research, C. A. ScotT, (2) II, 157164. (Vorträge über ausgewählte Fragen der Elementargeometrie, F. Klein, ausgearbeitet von F. Tägert, 1895.)

K23, Shorter notice, V. SNyder, (2) x, 207-209. (Leitfaden der Projections-Lehre, C. H. Müller and O. Presler, 1903.)

L.

Conics and surfaces of the second degree.

$\mathbf{I}^{1}$, Conics; $\mathbf{I}^{2}$, Quadrics.

$\mathbf{I}^{1}$, The synthetic treatment of conics at the present time, E. B. WILson, Dec. 29, 1902, (2) IX, 248-254.

I11c, 2a, On the Steiner points of Pascal's hexagon, V. SNyder, (2) Iv, 441-442.

$\mathbf{L}^{17}, 17$, On the locus of the foci of conics having double contact with two fixed conics, R. A. Roberts, Nov. 30, 1895, (2) II, 98-110.

I'18, (Q1, (2) III, 235-246).

$\mathbf{L}^{18} \mathbf{b}, \mathbf{B} 12 \mathrm{a}$, The status of imaginaries in pure geometry, C. A. Scotr, Oct. 28, 1899, (2) vI, 163-168.

$\mathbf{L}^{1} 10,11,13$, Some curious properties of conics touching the line infinity at one of the circular points, E. V. Huntington and J. K. WhitTeMORE, Oct. 26, 1901, (2) virI, 122-124; Correction, 419.

$\mathbf{I}^{1} 16 \mathrm{a}$, Note on a property of the conic sections, H. F. BuIchFeld (San Francisco) Dec. 20, 1902, (2) Ix, 306-307.

$\mathbf{L}^{1} 17$, H1h, On the differential equations of certain systems of conics, R. A. Robert's, Aug. 28, 1895, (2) II, 11-19.

$\mathbf{L}^{1} \mathbf{1 8 d}, \mathbf{L}^{2} \mathbf{1 7 i}$, On the parabolas (or paraboloids) through the points common to two given conics (or quadrics), T. J. I'A. BRomwICH, Apr. 26, 1902, (2) vIII, 386-388.

I'121a $\beta$, (J4f, (2) IV, 520-524).

I'217i, ( $\mathbf{L}^{1} 18 d$, (2) vIII, 386-388).

I, P, Niewenglowski's Geometry, M. Bôcher, (2) IV, 448-452. (Cours de géométrie analytique, $\mathbf{B}$. Niewenglowski, avec une note sur les transformations en géométrie, E. Borel, 1894-1896).

I, (K6, (2) III, 351-352).

I $^{1}$, Gundelfinger's Conic sections, F. MorLey, (2) II, 65-72. (Vorlesungen aus der analytischen Geometrie der Kegelschnitte, S. Gundelfinger, herausgegeben von F. Dingeldey, 1895). 
$\mathbf{L}^{1}$, Shorter notice, I. Madpison, (2) vI, 113-115. (Jacob Steiner's Vorlesungen iber synthetische Geometrie, Teil II: Die Theorie der Kegelschnitte gestützt auf projective Eigenschaften, bearbeitet von H. Schröter, 1898.)

$\mathbf{L}^{1},(\mathbf{K} 7,(2) \mathrm{VI}, 318-319 ;$ (2) $\mathrm{x}, 355-358)$.

$\mathbf{L}^{1} 8 \mathrm{~b}$, (B12a, (2) v, 175-181).

$\mathbf{L}^{2}$, Focal properties of surfaces of the second order, H. D. Thompson, (2) IV, 405-407. (Die Focaleigenschaften der Flächen zweiter Ordnung, O. Staude, 1896.)

M.

Algebraic curves and surfaces; special transcendental curves and surfaces.

$\mathbf{M}^{1}$, Plane algebraic curves; $\mathbf{M}^{2}$, Algebraic surfaces; $\mathbf{M}^{3}$, Algebraic curves in space; $\mathbf{M}^{ \pm}$, Transcendental curves and surfaces.

$\mathbf{M}^{1} 1 \mathrm{a}, 8 \mathrm{a}$, Note on the common tangents of two similar cycloidal curves, F. Moriey, Nov. 30, 1895, (2) II, 111-116.

$\mathbf{M}^{1} 1 \mathrm{1a}, 2$, On the intersections of plane curves, C. A. ScotT, (2) IV, 260273.

$\mathbf{M}^{1} 1 \mathrm{a}, 2 \mathrm{c}$, On the intersections of plane curves, F. S. Macaulay, (2) IV, 540-544.

M'1h, (Q3c, I, 197-202).

$\mathbf{M}^{1}$ 2c, d, Some observations on the modern theory of point groups, F. HARDCASTIE, (2) IV, 390-402.

$\mathrm{M}^{1} 3 \mathrm{3}$, (Q1, (2) III, 235-246).

$\mathbf{M}^{1} 4 \mathrm{a}$, D6ar, A geometric proof of a fundamental theorem concerning unicursal curves, W. F. OsGood, (2) II, 168-173.

I'5e $\alpha$, Inflexional lines, triplets, and triangles associated with the plane cubic curve, H. S. White, Feb. 26, 1898, (2) Iv, 258-260.

M¹6, (B6c, (2) I, 105-111).

$\mathbf{M}^{1} \mathbf{8 g}, \mathbf{N}^{2} 1$, On a system of plane curves having factorable parallels, $\mathrm{V}$. SNYDER, Dec. 28, 1900, (2) vII, 299-302.

M18g, A3, B6a, On the algebraic potential curves, E. KAsner, Feb. 23, 1901, (2) VII, 392-399.

$\mathbf{M}^{2}, \mathbf{M}^{3}$, V8, 9, Bibliography of surfaces and twisted curves, J. E. HILL, May 23, 1896, (2) III, 133-146.

$\mathbf{M}^{2},\left(\mathbf{N}^{1} 4 \mathrm{~b},(2) \mathrm{x}, 440-441\right)$.

$\mathbf{M}^{2} 1 \mathrm{~d}, 3 \mathrm{c}, \mathbf{B} 4 \mathrm{~d}$, The Hessian of the cubic surface, J. I. Hutchinson, I, Aug. 19, 1898, (2) v, 282-292; II, Feb. 24, 1900, (2) vI, 328-337.

$\mathbf{M}^{2} 1 d$, Linear systems of curves upon algebraic surfaces, H. S. WHITE, Sept. 2-5, 1902, (2) x, 120-124.

$\mathbf{M}^{2} 3$, On three types of surfaces of the third order regarded as double surfaces of translation, A. S. GaLE, Oct. 31, 1903, (2) x, 188-191.

M²3, (A4d, (2) viII, 63-70).

$\mathbf{M}^{2} 4$, Correction of an error in Salmon's Geometry of three dimensions, T. F. Holgate, III, 224. 
$\mathbf{M}^{2} \mathbf{4} \mathbf{f}, \mathbf{Q 2}$, On cyclical quartic surfaces in space of $n$ dimensions, V. SNYDER, Dec. 28, 1899, (2) vI, 194-198.

$\mathbf{M}^{2} 4 \mathbf{i} \delta$, F8f, O5j, Asymptotic lines on a circular ring, H. MaschKe, Aug. 28,1895 , (2) II, 19-21.

$\mathbf{M}^{2} 4 \mathrm{k}, 1$, Note on the tetrahedroid, J. I. Hunchinson, Feb. 26, 1898, (2) Iv, 327-329.

$\mathbf{M}^{2} 4 \mathbf{k}$, 05j, The asymptotic lines of the Kummer surface, J. I. HUTCHINson, Apr. 29, 1899, (2) v, 465-467.

$\mathbf{M}^{2} 4 \mathbf{k}$, P4, On some birational transformations of the Kummer surface into itself, J. I. Hutchinson, Dec. 28, 1900, (2) vII, 211-217.

M $^{2} 4 \mathrm{k},($ F8f, (2) vill, 148-153).

$\mathbf{M}^{2} 6 \mathrm{a}$, On the forms of quintic scrolls, V. SNYDER, Feb. 22, 1902, (2) viII, 293-296.

$\mathbf{M}^{2} 6 \mathrm{a}$, On the quintic scroll having three double conics, V. SNyder, Oct. $25,1902,(2)$ IX, 236-242.

$\mathbf{M}^{2} 6$ a, On directrix curves of quintic scrolls, C. H. SISAM, Apr. 25, 1903, (2) $x, 32-34$.

$\mathbf{M}^{2} 9 \mathbf{e}, \mathbf{M}^{4} \mathbf{n}, \mathbf{B} 6 \mathrm{a}$, Some properties of potential surfaces, E. KASNer, Apr. 27,1901 , (2) VIII, 243-248.

$\mathbf{M}^{3},\left(\mathbf{M}^{2}\right.$, (2) III, 133-146).

$\mathbf{M}^{35}$, (B6c, (2) I, 105-111).

$\mathbf{M}^{4} \mathrm{n},\left(\mathbf{M}^{2} 9\right.$ e, (2) vIII, 243-248).

M', M'4, Loria's Special plane curves, E. B. Wirson, (2) Ix, 492-501. (Spezielle algebraische und transcendente ebene Curven, Theorie und Geschichte, G. Loria, deutsche Ausgabe von F. Schütte, 1902.)

$\mathbf{M}^{1}$, (B, (2) vII, 360-361).

$\mathbf{M}^{1} 6 \mathrm{~b}, \mathbf{M}^{2} 4 \mathbf{f}, \mathbf{i}$, Darboux's Memoir on cycliques, R. A. RoBerts, (2) II, 249-255. (Sur une classe remarquable de courbes et de surfaces algébriques et sur la théorie des imaginaires, G. Darboux, 1896.)

$\mathbf{M}^{2}$, Scheffers's Theory of surfaces, J. M. PAGE, (2) vIII, 332-341. (Anwendung der Differential- und Integral-Rechnung auf Geometrie, Band 2: Einführung in die Theorie der Flächen, G. Scheffers, 1902.)

$\mathbf{M}^{2} 4 \mathbf{f}, \mathbf{i}$, ( $\mathbf{M}^{1} 6 \mathrm{~b}$, (2) II, 249-255).

$\mathbf{M}^{2} 9$ d, e, Shorter notice, C. L. E. Moore, (2) x, 406-408. (Etude de quelques surfaces algébriques engendrées par des courbes du second et du troisieme ordre, M. Stuyvaert, 1902.)

$\mathbf{M}^{3}$, Schell's Tortuous curves, A. Zrwet, (2) Iv, 346-349. (Allgemeine Theorie der Curven doppelter Krümmung in rein geometrischer Darstellung, W. Schell, 1898.)

$\mathbf{M}^{35}$, X8, Shorter notice, V. SNyder, (2) X, 409-410. (Die Horopterkurve mit einer Einleitung in die Theorie der kubischen Raumkurve, W. Tudwig, 1902.)

$\mathbf{M}^{4},\left(\mathbf{M}^{1},(2) \mathrm{Ix}, 492-501\right)$. 
N.

Complexes and congruences; connexes; systems of curves and of surfaces; enumerative geometry.

$\mathbf{N}^{1}$, Complexes; $\mathbf{N}^{2}$, Congruences; $\mathbf{N}^{3}$, Connexes; $\mathbf{N}^{4}$, Non-linear systems of curves and of surfaces, enumerative geometry.

$\mathbf{N}^{1} 1,2$, Lines common to four linear complexes, V. SNyder, Feb. 27, 1897, (2) III, 247-250.

$\mathbf{N}^{11}$, (F8f, (2) vIII, 148-153).

$\mathbf{N}^{1} 1 \mathrm{~h}, \mathbf{P} 2 \mathrm{a}$, Some remarks on tetrahedral geometry, H. E. Timerding, June 27, 1900, (2) vI, 417-430.

$\mathbf{N}^{1} 2$, $\mathbf{O}$, Geometry of some differential expressions in hexaspherical coordinates, V. SNyder, Aug. 16, 1897, (2) IV, 144-154.

$\mathbf{N}^{1} 2, \mathbf{N}^{4} 1$ b, On the geometry of the circle, V. SNyder, Dec. 28, 1899, (2) vI, 319-322; Correction, 464.

$\mathbf{N}^{1} 4 \mathrm{~b}, \mathbf{M}^{2}$, On self-dual scrolls, C. H. Sisam, Apr. 30, 1904, (2) x, 440441.

$\mathbf{N}^{2} 1$, (M18g, (2) VII, 299-302).

N21a, (O6k, (2) virI, 301-303).

$\mathbf{N}^{4} 1$ b, ( $\mathbf{N}^{1} 2$, (2) vI, 319-322).

$\mathbf{N}^{1} 1$, O, Line geometry, V. SNyder, (2) IV, 28-31. (La géométrie réglée et ses applications, G. Koenigs, 1895.)

$\mathrm{N}^{1} 1, \mathbf{N}^{2} 1$, Shorter notice, L. E. Dickson, (2) Ix, 561-562. (Liniengeometrie mit Anwendungen, Band 1, K. Zindler, 1902.)

$\mathbf{N}^{1} 1$, (R3, (2) x, 193-200).

$\mathbf{N}^{2} 1,\left(\mathbf{N}^{1} 1,(2) \mathrm{IX}, 561-562\right)$.

o.

Infinitesimal geometry and the geometry of motion; applications of differential and integral calculus to the theory of curves and surfaces; quadrature and rectification; curvature; asymptotic and geodesic lines and lines of curvature; areas; volumes; minimal surfaces; orthogonal systems.

O, (N12, (2) IV, 144-154; Q2, (2) vII, 88-100).

$\mathbf{0} 2 \mathrm{~m}, \mathrm{H} 2 \mathrm{c} \gamma$, The Riccati differential equations which represent isothermal systems, E. K.Asner, Dec. 29, 1903, (2) x, 341-346.

O2m, H2c $\gamma$, Riccati isothermal systems-a correction, E. KASNER, (2) $\mathrm{x}, 405$.

04f, Asymptotic lines on ruled surfaces having two rectilinear directrices, V. SNyder, Aug. 19, Dec. 29, 1898, (2) v, 343-353.

05, Surfaces referred to their lines of length zero, L. P. Eisenhar'r, Oct. 25, 1902, (2) Ix, 242-245.

05e, $6 \mathrm{~s}$, Surfaces whose first and second fundamental forms are the second and first respectively of another surface, L. P. EIsenHART, Feb. 23, 1901, (2) vII, 417-423.

05e, $6 \mathrm{~s}$, Concerning surfaces whose first and second fundamental forms are the second and first fundamental forms respectively of another surface, A. Pell, Aug. 20, 1901, (2) virI, 27-28. 
O5j, ( $\mathbf{M}^{2} 4 \mathbf{i} \delta$, (2) II, 19-21; $\mathbf{M}^{2} 4 \mathrm{k}$, (2) v, 465-467).

O5m, n, Lines of length zero on surfaces, L. P. EisenharT, Dec. 28, 1901, (2) vIII, 241-243.

O5n, 6a, Surfaces of revolution in the theory of Lamé's products, F. H. SAFFORD, Feb. 25, 1899, (2) v, 431-437.

06, A demonstration of the impossibility of a triply asymptotic system of surfaces, L. P. Ersenhart, Dec. 28, 1900, (2) vII, 184-186.

06, Possible triply asymptotic systems of surfaces, L. P. Eisenhart, Feb, 23, 1901, (2) vir, 303-305.

06a, k, Infinitesimal deformation of the skew helicoid, L. P. Eisenhart, Sept. 3, 1902, (2) IX, 148-152.

O6k, $\mathbf{N}^{2} 1$ a, Note on isotropic congruences, L. P. Eisenhart, Dec. 28, 1901 , (2) vIII, 301-303.

06q, Note on Stokes's theorem in curvilinear coordinates, A. G. WeBster, Apr. 30, 1898, (2) IV, 438-441.

O, Scheflers's Differential geometry, J. M. PAGE, (2) viI, 144-149. (Anwendung der Differential- und Integral-Rechnung auf Geometrie, Band 1: Einführung in die Theorie der Curven in der Ebene und im Raum, G. Scheffers, 1901.)

O, Shorter notice, G. O. JAMEs, (2) vir, 359-360. (Lezioni sulle teoria delle superficie, G. Ricci, 1898.)

O, Shorter nutice, L. P. Lisenhart, (2) viI, 408-410. (Leçons nouvelles sur les applications géométriques du calcul différentiel, W. de 'Tannenberg, 1899.)

o, Bianchi's Differential geometry, J. K. Whitтemore, (2) vir, 431442. (Vorlesungen iiber Differentialgeometrie, L. Bianchi, deutsche Uebersetzung von M. Lukat, 1896-1899.)

o, Cesàro's Intrinsic geometry, V. SNYDER, (2) Ix, 349-357. (Lezioni di geometria intrinseca, E. Cesàro, 1896 ; E. Cesàro, Vorlesungen iiber natïrliche Geometrie, deutsche Uebersetzung von G. Kowalewski, 1901.)

O, (B12c, (2) vir, 231-233; C, III, 39-65; D, (2) vI, 204-212; N11, (2) Iv, 28-31; P1, (2) v, 362-366; Q1, 2, (2) v, 300-308).

06p, q, Q2, Darboux's Orthogonal systems, E. O. LoveTt, (2) v, 185202. (Leçons sur les systèmes orthogonaux et les coordonnées curvilignes, $G$. Darboux, Tome 1, 1898.)

08, The geometry of movement, F. Morley, (2) v, 476-480. (Geometrie der Bewegung in synthetischer Darstellung, A. Schoenflies, 1886. La géométrie du mouvement, exposé synthétique, translated by $\mathrm{C}$. Speckel, 1893.)

08, (R1, (2) VI, 299-304).

$\mathbf{P}$.

Geometric transformations; homography; homology and affinity; correlation and reciprocal polars: inversion; birational trans. formations and other transformations.

P, (J4, (2) vII, 259-266, V1, II, 215-249). 
P1, Collineation as a mode of motion, M. Bôcher, June 4, 1892, I, 225231.

P1, J4f, On singular transformations in real projective groups, H. B. Newson, Apr. 28, 1900, (2) vI, 431-439.

$\mathbf{P 1}$, On the condition that a point transformation of the plane be a projective transformation, E. SwIFT, Oct. 31, 1903, (2) x, 247-254; Acknowledgment, 361.

P1, (J4f, (2) IV, 515-519).

$\mathbf{P 1 b}$, Collineations in a plane with invariant quadric or cubic curves, H. S. White, Aug. 17, 1897, (2) Iv, 17-23.

P1b, The characterization of collineations, E. KASNER, Feb. 28, 1903, (2) $\mathrm{Ix}, 545-546$.

P1b, (Q1, (2) III, 235-246).

P2a, ( $\mathbf{N}^{1} 1 \mathrm{~h},(2)$ vI, 417-430).

P3, On the transformation of the boundary in the case of conformal mapping, W. F. OsGood, Dec. 30, 1902, (2) Ix, 233-235.

P4, ( $\mathbf{M}^{2} 4 \mathrm{k}$, (2) vII, 211-217).

$\mathbf{P} 4 \mathrm{~b}$, K6b, Reciprocal transformations of projective coordinates and the theorems of Ceva and Menelaos, A. ЕмсH, (2) v, 143-150.

P4b, (J4f, (2) vII, 340-350).

$\mathbf{P 6}$, J4f, Certain classes of point transformations in the plane, E. $\mathrm{O}$. LoverT, May 29, 1897, (2) 1v, 97-107.

$\mathbf{P 6}$, J4f, On the generation of finite from infinitesimal transformationsa correction, H. B. Newson, (Chicago) Jan. 2, 1903, (2) x, 191-193.

P6, (B2, (2) IV, 107-121).

P6a, On a memoir by Riccardo de Paolis, C. A. Scott, (2) vII, 24-38.

P6e, Note on contact transformations, E. O. Lovetr, (2) IV, 402-404.

P, Shorter notice, A. S. GALE, (2) X, 512-514. (Geometrische Transformationen, Teil I: Die projektiven Transformationen nebst ihren Anwendungen, K. Doehlemann, 1902.)

P, (K, III, 33-36 ; K6, 7, (2) II, 265-271; K7, (2) VI, 254-255; (2) vII, $318-319$; I, (2) IV, 448-452).

P1, O, D'Ocagne's Descriptive and infinitesimal geometry, E. O. LoverT, (2) $\mathrm{v}, 362-366$. (Cours de géométrie descriptive et de géométrie infinitésimale, M. d'Ocagne, 1896.)

P4, Shorter notice, F. MorLey, (2) III, 195-196. (A geometrical treatment of curves which are isogonal conjugate to a straight line with respect to a triangle, Part 1, I. J. Schwatr, 1895.)

P6, (R3, (2) X, 193-200).

P6e, J4f, Iie's Geometry of contact transformations, E. O. LovetT, (2) IIr, 321-350. (Geometrie der Berührungstransformationen, S. Lie und G. Scheffers, Band I, 1896.) 
Q.

Geometries of various kinds; geometry of $n$ dimensions; non-euclidean geometry; analysis situs; geometry of position.

Q, (A, (2) vIII, 437-479; V8, III, 79-80).

Q1, On the non-euclidian geometry, E. MCCLINTock, II, 21-33.

Q1, A case of non-euclidian geometry, W. W. Johnson, Mar. 4, 1893, II, 158-161.

Q1, L'1, M13a, P1b, On Cayley's theory of the absolute, C. A. Scott, Jan. 30, 1897, (2) III, 235-246.

Q1, Hyperbolea and the solution of equations, C. H. Hinton, (2) III, 309-321.

Q1,2, The philosophy of hyperspace, presidential address, S. NewCOMB, Dec. 29, 1897, (2) IV, 187-195.

Q1, (V8, 9, II, 144-147).

Q1a, J5, Is continuity of space necessary to Euclid's geometry? W. M. Strong, Apr. 30, 1898, (2) IV, 443-448.

Q1c, (V9, (2) I, 165-180).

Q2, Condition that the line common to $n-1$ planes in an $n$-space may pierce a given quadric surface in the same space, V. SNYDER, (2) Iv, 68-73.

Q2, O, Note on geometry of four dimensions, E. O. LovetT, Apr. 28, 1900, (2) vII, 88-100.

Q2, Concerning the angles and the angular determination of planes in 4-space, C. J. KeYSER, Apr. 26, 1902, (2) vIII, 324-329.

Q2, (B12d, (2) IV, 54-57; M²4f, (2) vI, 194-198).

Q3, On the theorem of analysis situs. relating to the division of the plane or of space by a closed curve or surface, L. D. AmEs, Dec. 29,1903 , (2) $\mathrm{x}, 301-305$.

Q3, The exterior and interior of a plane curve, G. A. BuIss, (2) $\mathrm{x}$, 398-404.

Q3a, Numerically regular reticulations upon surfaces of deficiency higher than 1, H. S. WHite, (2) III, 116-121.

Q3a, The construction of special regular reticulations on a closed surface, H. S. Whrte, Apr. 30, 1898, (2) IV, 376-382.

Q3a, Note on special regular reticulations, E. W. Davis, (2) IV, 529-530.

Q3c, $\mathbf{M}^{1} 1 \mathrm{~h}$, Topology of algebraic curves, L. S. HuLBURT, I, 197-202.

Q4a, On a regular configuration of ten line pairs conjugate as to a quadric, F. MoRLEY, Oct. 29, 1898, (2) v, 252-253.

Q4a, (K7, (2) I, 116-124).

Q4c, B12c, On the problem of the minimum sum of the distances of a point from given points, V. SchlEgEL, translated by A. ZIwET, Aug. 15, 1894, (2) I, 33-52.

Q4c, V9, Note on the history of the map coloring problem, I. Maddison, (2) III, 257.

Q, (I, II, 37-46) . 
Q1, 2, O, Three memoirs on geometry, E. O. LovETT, (2) v, 300-308. ('Thèse sur la géométrie non-euclidienne, L. Gérard, 1892 ; Lezioni di geometria intrinseca, E. Cesàro, 1896; L'hyperespace à $(n-1)$ dimensions, G. Fontené, 1892.)

Q1, Non-euclidean geometry, J. L. Coolidge, (2) vII, 428-431. (Noneuclidean geometry, H. P. Manning, 1901.)

Q1a, V1, Hilbert's Foundations of geometry, J. Sommer, (2) vi, 287299 ; H. Poincare, translated by E. V. Huntington, (2) x, 1-23. (Grundlagen der Geometrie, D. Hilbert, 1899.)

Q1a, V1, The English and French translations of Hilbert's Grundlagen der Geometrie, E. R. Hevrick, (2) Ix, 158-165. (Les principes fondamentaux de la géométrie, D. Hilbert, traduit par L. Laugel, 1900 ; The foundations of geometry, D. Hilbert, translated by E. J. Townsend, 1902.)

Q1a, (K, (2) x, 504-510).

Q1b, V9, Lobachevsky's geometry, F. S. Woods, (2) vI, 339-344, 443452. (Nikolaj Iwanowitsch Lobatschefskij, zwei geometrische Abhandlungen aus dem Russischen übersetzt von F. Engel, 1899.)

Q2, (I4aß, (2) vI, 30-31; 06p, q, (2) v, 185-202).

R.

General mechanics; kinematics; statics, inchuding centers of gravity and moments of inertia; dynamics; mechanics of solids; friction; attraction of ellipsoids.

$\mathbf{R}$, Nomenclature of mechanics, T. W. Wright, I, 46-48.

R, (V7, (2) III, 363-371; V8, 9, (2) VI, 133-163).

R1, The mechanical axioms or laws of motion, W. W. Jorrsson, r, 129-139.

R1d, Note on the projections of the absolute acceleration in relative motion, G. O. JAMES, (2) Ix, 143-147.

R3a, H1da, J4f, The analytic theory of displacements, R. W. H. T. Hudson, Dec. 30, 1902, (2) Ix, 308-328.

R5, V8, Early history of the potential, A. S. Hatraway, I, 66-74.

R7b, Kinetic stability of central orbits, W. W. Johnson, Apr. 27, 1895, (2) I, 193-196.

R7ba, (U1, (2) v, 18-21).

R7d, The determination of the constants in the problem of the brachistochrone, O. Bolza, (2) x, 185-188.

R7d, On doubly infinite systems of directly similar convex arches with common base line, E. H. Moore, (2) x, 337-341.

R8c, On the motion of a homogeneous sphere or spherical shell on an inclined plane taking into account the rotation of the earth, A. S. Chessin, (2) II, 302-309.

R8c, On the stability of a sleeping top, F. KleIN, Oct. 17, 1896, (2) III, 129-132, Correction, 292.

R, Shorter notice, A. ZIweT, (2) I, 73. (H. Hertz: Gesammelte Werke, Band III: Die Prinzipien der Mechanik in neuem Zusammenhange dargestellt, 1894.) 
R, H3b, Painleve's Lectures on dynamics, A. S. CHessin, (2) II, 164168. (Leçons sur l'intégration des équations différentielles de la mécanique et applications, P. Painlevé; Leçons sur le frottement, P. Painlevé, 1895.)

R, S, T, Shorter notice, A. S. MAckenzIE, (2) IV, 276-277. (Elements of theoretical physics, C. Christiansen, translated by W. F. Magie, 1897.)

R, Love's Theoretical mechanics, W. H. Macaulay, (2) IV, 340-345. (Theoretical mechanics, an introductory treatise on the principles of dynamics, A. E. H. Love, 1897.)

R, Shorter notice, E. W. Brown, (2) vI, 28-29. (Vorlesungen über mathematische Physik, Band 1: Mechanik, G. Kirchhoff, 4te Auflage von W. Wien.)

R, C, Shorter notice, E. W. Brown, (2) vI, 115-116. (Compositions d'analyse, cinématique, mécanique et astronomie données depuis 1889 à la Sorbonne pour la licence ès sciences mathématiques, E. Villié, 1898.)

$\mathbf{R}, \mathbf{s}$, Applied mathematics, E. W. Brown, (2) vi, 249-252. (Cinématique et mécanismes, potentiel et mécanique des fluides, $H$. Poincaré, 1899.)

R, Some recent books on mechanics, E. B. WILson, (2) VIII, 341-349, 403-412; (2) IX, 25-39. (The principles of mechanics, Part I, F. Slate, 1900 ; A treatise on elementary dynamics, H. A. Roberts, 1900; Die Dynamik der Systeme starrer Körper, E. J. Routh, deutsche Ausgabe von A. Schepp, 1898-1900.-A treatise on physics, volume 1, A. Gray, 1901; Cours de mécanique, C. Cellérier, 1892 -Vorlesungen über technische Mechanik, A. Föppl, 1900-1901; Einführung in das Studium der theoretischen Physik, P. Volkmann, 1900 ; Quelques réflexions sur la mécanique, E. Picard, 1902.)

R, Mach's Mechanics, E. B. Wilson, (2) x, 80-86. (The science of mechanics-a critical and historical account of its development, $\mathrm{E}$. Mach, translated by T. J. MeCormack, 1902.)

R, Shorter notice, A. S. Gale, (2) x, 359-360. (Leçons de mécanique élémentaire, P. Appell et J. Chappuis, 1903.)

R, (B12d, III, 179-185; I, II, 37-46).

R1, Some recent elementary works on mechanics, A. ZIwET, I, 145-150. ('The laws of motion, W. H. Laverty, 1889.)

R1, 08, Koenigs' Lectures on kinematics, E. O. LovErr, (2) vi, 299-304. (Leçons de cinématique, G. Koenigs, 1897.)

R3, P6, N ${ }^{1} 1$, Study's Geometry of dynames, V. SNyder, (2) x, 193-200, 470-471. Reply by the author, (2) x, 468-470. (Geometrie der Dynamen, die Zusammensetzung von Kräften und verwandte Gegenstände der Geometrie, E. Study, 1903.)

R8c $\beta$, Shorter notice, H. D. THompson, (2) V, 486-487. (The mathematical theory of the top, F. Klein, 1897.)

\section{S.}

Mechanics of fluids; hydrostatics; hydrodynamics; thermodynamics.

S, ( V8, 9, (2) VI, 133-163). 
S, (D6e, (2) II, 255-265; H, (2) vIII, 81-85; R, (2) IV, 276-277; (2) VI, 249-252).

S2, Fluid motion, E. W. Brown, (2) IV, 73-80. (Hydrodynamics, H. Lamb, 1895.)

S2, Hydrodynamic action at a distance, E. B. WILson, (2) x, 139-153. (Vorlesungen iiber hydrodynamische Fernkräfte nach C. A. Bjerknes's Theorie, V. Bjerknes, 1900-1902.)

S2a, The theory of waves, E. B. WILson, (2) x, 305-317. (Leçons sur la propagation des ondes et les équations de l'hydrodynamique, J. Hadamard, 1903.)

S2c, Papers of Mr. Charles Chree on vortices in a compressible and rotating fluid, C. ABBE, III, 36-38.

S4, Buckingham's Thermodynamics, E. H. HaLl, (2) Ix, 173-175. ('Theory of thermodynamics, E. Buckingham, 1900.)

S4, Shorter notice, E. B. Wilson, (2) x, 157. (Réflexions sur la puissance motrice du feu et sur les machines propres à développer cette puissance, S. Carnot, réimpression facsimile, 1903.)

\section{T.}

Mathematical physics; elasticity; strength of materials; capillarity; light; heat; electricity.

T1, Gravitation and absolute units of force, W. W. Johnson, Apr. 7, 1894, IIr, 197-199.

T2, H5i, Notes on the expression for a velocity-potential in terms of functions of Laplace and Bessel, J. McMarion, Dec. 27, 1895, (2) II, $173-177$.

T2a, (V8, II, 107-109).

T, (D6e, (2) II, 255-265; H, (2) VIII, 81-85; R, (2) IV, 276-277).

T2b, The strength of materials, C. CHREE, (2) vII, 131-144. Errata, 234. (The strength of materials, J. A. Ewing, 1899.)

T3, The theory of light, J. E. Davies, I, 75-78. (The theory of light, T. Preston, 1890.)

T4, (D, (2) VI, 78-84).

T5, 6,7, Recent researches in electricity and magnetism, G. O. SQUièr, III, 107-111. (Notes on recent researches in electricity and magnetism, J. J. Thomson, 1893.)

T5, 6, 7, Electricity and magnetism, A. S. MAckenzIE, (2) II, 329-332. (Elements of the mathematical theory of electricity and magnetism, J. J. Thомson, 1895.)

T5, 6, 7, Shorter notice, E. B. Wilson, (2) x, 266-267. (Wissenschaftliche Grundlagen der Elektrotechnik, G. Ferraris, deutsch herausgegeben von L. Finzi, 1901.)

T6, (U, (2) vIr, 272-278.)

T7c, Alternating current phenomena, J. B. WhIteHEAD, Jr., (2) vII, 399-408. (Alternating current phenomena, C. P. Steinmetz, 1900.) 
U.

Astronomy; celestial mechanics and geodesy.

U, V9, Remarks on the progress of celestial mechanics since the middle of the century, presidential address, G. W. HILL, Dec. 27, 1895, (2) II, 125-136.

U, (V8, 9, (2) vI, 133-163).

$\mathrm{U} 1, \mathbf{R} 7 \mathbf{b} a$, Note on the periodic developments of the equation of the center and of the logarithm of the radius vector, A. S. CHessin, (2) v, $18-21$.

U3, 4, 5, H, Modern methods of treating dynamical problems and in particular the problem of three bodies, E. W. Brown, Aug. 21-24, 1901, (2) vIII, 103-113.

U3, (D2b, (2) II, 93-97).

U7, The motions of the atmosphere and especially its waves, E. HERRMANN, translated by C. ABBE, (2) II, 285-296.

U, Catalogue of the Astronomische Gesellschaft, T. H. SAFrord, I, 33-39. (Catalog der Astronomischen Gesellschaft, 1890.)

U, The photochronograph, H. JACOBY, I, 44-46. (The photochronograph and its application to star transits, J. G. Hagen and G. A. Fargis, 1891.)

U, Perturbations of the four inner planets, S. Newcomb, I, 120-122. (Periodic pertubations of the longitudes and radii vectores of the four inner planets of the first order as to the masses, computed. under the direction of $\mathrm{S}$. Newcomb, 1891.)

U, Spherical and practical astronomy, J. K. REES, I, 140-141. (An introduction to spherical and practical astronomy, D. Greene, 1891.)

U, Poincarë's Mécanique céleste, E. W. Brown, I, 206-214. (Les méthodes nouvelles de la mécanique céleste, tome 1 , H. Poincaré, 1892.)

U, Recent star catalogues, T. H. SAFFord, II, 46-48. (Zweites Münchener Sternverzeichnis, enthaltend die mittleren Oerter von. 13200 Sternen, für das Aequinoctium, 1880, beobachtet und berechnet von J. Bauschinger, 1891.)

U, The lunar theory, E. W. Brown, III, 207-215. (Traité de mécanique celeste, volume $3, \mathrm{~F}$. 'Tisserand, 1894.)

U, Celestial mechanics, E. W. Brown, (2) III, 9-29. (Astronomical papers prepared for the use of the American ephemeris and nautical almanac, volumes $5,6,7,1894-1895$.)

U, Shorter notices, E. W. Brown, (2) III, 196-198; (2) IV, 353-354; (2) v, 260 ; (2) VI, 252-253; (2) VII, 233-234; (2) vIII, 260-261; (2) Ix, 381-382; (2) $\mathrm{x}, 360-361$. (Annuaire publié par le Bureau des Longitudes, pour les ans 1897-1904.)

U, Shorter notices, E. W. Brows, (2) v, 259, 260-261. (Leçons de cosmographie, F. Tisserand et H. Andoyer; L'ora esatta dappertutto, etc., M. Rajna.)

U, Shorter notice, E. W. Brown, (2) vI, 27-28. (Leçons sur la determination des orbites, F. Tisserand, rédigées et developpées pour les calculs numériques par J. Perchot, 1899.) 
U, Shorter notice, E. W. Brown, (2) vI, 116. (Keplers Traum vom Mond, L. Günther, 1898.)

U, T6, Adams's unpublished papers, E. W. Brown, (2) vII, 272-278. ('The scientific papers of John Couch Adams, volume 2, part 1: Extracts from unpublished manuscripts, R. A. Sampson, 1900; part 2: Terrestrial magnetism, W. G. Adams, 1900; Lectures on the lunar theory, R. A. Sampson, 1900.)

U, Brown's Lunar theory, F. R. MouLton, (2) IX, 254-263. (An introductory treatise on the lunar theory, E. W. Brown, 1896.)

U, Shorter notice, E. W. Brown, (2) x, 205-206. (Problems in astrophysics, A. M. Clerke, 1903.)

U, (V, (2) vII, 187-188; V4c, (2) vII, 188-190; V9, (2) III, 225-227).

U7, The mechanics of the atmosphere, R. S. Woodward, II, 199-203. (The mechanics of the earth's atmosphere, a collection of translations, C. Abbe, 1891.)

U8, Two books on tides, E. W. Brown, (2) v, 406-413. (The tides and kindred phenomena of the solar system, G. H. Darwin, 1898; Leçons sur la théorie des marées, M. Lévy, 1898.)

U10, West African longitudes, H. JACOBY, I, 27-28. (Telegraphic determinations of longitudes on the west coast of Africa, D. Gill, 1891.)

U10, South American longitudes, H. J determination of longitudes in Mexico, Central America, the West Indies, and on the north coast of South America, J. A. Norris and C. Laird, 1891.)

U10, Shorter notice, E. W. Brown, (2) vI, 253-254. (Elements of precise surveying and geodesy, M. Merriman, 1899.)

U10, Shorter notice, V. SNyder, (2) X, 408-409. (Das Erdsphäroid und seine Abbildung, E. Haentzschel, 1903.)

V.

Philosophy and history of the mathematical sciences; biographies of mathematicians.

v, The past and future of the American Mathematical Society, presidential address, E. MuClintock, Dec. 28, 1894, (2) I, 85-94.

V, The new mathematical encyclopaedia, J. Pienpont, (2) v, 202-207.

V, B12h, H12, On the history of the extensions of the calculus, J. G. HAGEN, (2) vi, 381-390.

V1, P, J4, A comparative review of recent researches in geometry, F. KLEIN, translated by M. W. HASKELL, II, 215-249.

V1, Inaugural address, delivered at the general session of the Congress of Mathematics and Astronomy at Chicago, F. KLEIN, III, 1-3.

V1, Modern mathematical thought, Dec. 28, 1893, S. Newcomb, III, 95-107.

V1, The arithmetizing of mathematics, F. KLEIN, translated by I. Maddison, (2) II, 241-249.

V1, The relations of analysis and mathematical physics, H. PoIncare, translated by C. J. KEYSER, (2) IV, 247-255. 
V1, On the arithmetization of mathematics, J. Pienpont, Feb. 25, 1899, (2) $\mathrm{v}, 394-406$.

V1, On the foundations of mathematics, presidential address, E. H. Moore, Dec. 29, 1902, (2) IX, 402-424.

V1, J5, Concerning the axiom of infinity and mathematical induction, C. J. KeYSER, Dec. 29, 1902, (2) IX, 424-434.

V1, On some tendencies in geometric investigations, C. SEgre, translated by J. W. Young, (2) $\mathrm{x}, 442-468$.

V1, (J1, I, 189-193; J4e, (2) 1x, 346-348).

V1a, Instruction in mathematics in the United States, T. H. SAFFord, III, 4-8.

V1a, The teaching of mathematics at Güttingen, III, 80-88.

V1a, The teaching of mathematics in the secondary schools, III, 127-130.

V1a, Mathematical instruction in France, J. Pierpont, (2) vI, 225-249.

V1a, The undergraduate mathematical curriculum, report of the discussion at the seventh summer meeting of the American Mathematical Society, W. H. Maltbie, (2) viI, 14-24.

V1a, Pure mathematics for engineering students, A. S. Hathaway, (Chicago) Dec. 28, 1900, (2) vIr, 266-271.

V1a, Report of the committee of the American Mathematical Society on definitions of college entrance requirements in mathematics, Aug. 31,1903 , (2) $x, 74-77$.

V1a, Report on the requirements for the master's degree, (Chicago) Jan. $1,1904,(2) \mathrm{x}, 380-385$.

V3, I1, Limitations of Greek arithmetic, H. E. Hawkes, Apr. 30, 1898, (2) IV, 530-535.

V7, Was the binomial theorem engraven on Newton's monument? F. CAJORI, (2) I, 52-54.

V7, R, Newton's theory of kinetics, W. H. Macaulay, (2) III, 363-371; Errata, (2) IV, 283.

V8, H5ia, T2a, A bit of mathematical history, M. BôchER, II, 107-109.

V8, 9, Q1, On the early history of the non-euclidian geometry, E. MCClIN'TOCK, II, 144-147.

V8, Q, Lambert's non-euclidean geometry, G. B. HaLsTed, IIr, 79-80.

V8, D2aa, Note upon the history of the rules of convergence in the eighteenth century, G. ENESTröm, III, 186-187.

V8, A4, Jagrange's place in the theory of substitutions, J. Pierpont, (2) I, 196-204.

V8, Euler's use of $i$ to represent an imaginary, W. W. Beman, (2) IV, $274,551$.

V8, $9, \mathbf{R}, \mathbf{S}, \mathbf{U}$, The century's progress in applied mathematics, presidential address, R. S. Woodward, Dec. 28, 1899, (2) vI, 133-163.

V8, (R5, I, 66-74).

V8, 9, ( $\mathbb{M}^{2}$, (2) InI, 133-146).

v9, Emile Mathieu, his life and works, P. Dunem, translated by A. ZiWET, I, 156-168. 
V9, D6j, Kronecker and his arithmetical theory of the algebraic equation, H. B. Frne, I, 173-184.

V9, D1b, Wronski's expansion, W. H. Ecrols, II, 178-184.

V9, Lobachèvsky as algebraist and analyst, A. VAsILIEV, III, 231-235.

V9, Arthur Cayley, C. A. Scotr, (2) I, 133-141.

V9, D5, Q1c, Riemann and his significance for the development of modern mathematics, F. KLEIN, translated by A. ZIwET, (2) I, 165-180.

V9, Hubert Anson Newton, A. W. PhILlIPs, (2) III, 169-173.

V9, James Joseph Sylvester, F. FrankuIN, (2) III, 299-309.

V9, A4, Early history of Galois's theory of equations, J. PIERPont, Feb. 26, 1897, (2) IV, 332-340.

v9, Sophus Lie, G. Darboux, translated by E. O. LoveTt, (2) v, 367370.

V9, Notice sur M. Hermite, C. Jordan, (2) vII, 278-282.

V9, Lazarus Fuchs, E. J. WILCZYNski, (2) IX, 46-49.

V9, B12c, Josiah Willard Gibbs, Ph.D., LL.D., a short sketch and appreciation of his work in pure mathematics, P. F. SmITH, (2) $x$, 34-39.

V9, (B4c, (2) V, 161-175; H, II, 119-134; I1, (2) vII, 306-307; Q4c, (2) III, 257 ; U, (2) II, 125-136).

V, A new Italian mathematical journal, A. ZIweT, I, 42-43. (Rivista di matematica, 1891.)

V, Mathematical bibliography, A. ZIwET, II, 190-192. (Revue semestrielle des publications mathématiques, volume 1, part 1, 1893.)

V, Classification of mathematics, A. ZrweT, II, 258-259. (Index du répertoire bibliographique des sciences mathématiques, 1893.)

V, Cajori's History of mathematics, D. E. SMITH, III, 190-197, 250-251. (A history of mathematics, F. Cajori, 1894.)

V, Note on Smith's review of Cajori, G. B. HALsted, IIr, 248-250.

V, Shorter notice, A. ZIweT, (2) I, 76. (Proceedings of the American Association for the Advancement of Science, 1894.)

V, A card catalogue of mathematical literature, A. ZIwET, (2) I, 186189. (Répertoire bibliographique des sciences mathématiques, 1894.)

V, K20, Shorter notices, F. CAJoRI, (2) vI, 404-406. (Vorlesungen über Geschichte der Trigonometrie, A. von Braunmühl, Teil I, 1900; Histoire des mathématiques, J. Boyer, 1900.

V, U, Shorter notice, E. W. Brown, (2) vII, 187-188. (A short history of astronomy, A. Berry, 1899.)

V, Shorter notices, D. E. SmITH, (2) Ix, 376-381. (Urkunden zur Geschichte der Mathematik im Mittelalter und der Renaissance, M. Curtze, Teil 2, 1902; Abhandlungen zur Geschichte der mathematischen Wissenschaften, Heft XIV, 1902.) 
V, K20, Shorter notice, F. CAJoRI, (2) x, 153-157. (Vorlesungen iiber Geschichte der Trigonometrie, Teil 2, A. von Braunmühl, 1903.)

V, Shorter notice, F. CAJORI, (2) x, 206-207. (Opinions et curiosités tcuchant la mathématique, série 2, G. Maupin, 1902.)

V, (A1, I, 26).

V1, Shorter notice, H. D. Trompson, (2) IV, 355-356. (Erkenntnistheoretische Grundzüge der Naturwissenschaften, P. Volkmann, 1896.)

V1, Shorter notice, A. ZIwET, (2) V, 264-265. (L'Enseignement mathematique.)

V1, Pascal's Repertorium of higher mathematics, E. O. LovETT, (2) v, 357-362. (Repertorio di matematiche superiori, I: Analisi, E. Pascal, 1898.)

V1, Tannery's Arithmetic, J. Pierpont, (2) v, 455-457. (Leçons d'arithmétique théorique et pratique, J. Tannery, 1894.)

V1, Shorter notice, J. PIERPont, (2) v, 485-486. (Verhandlungen des ersten internationalen Mathematiker-Kongresses in Zürich, $\mathrm{F}$. Rudio, 1898.)

V1, 6,7,8, Shorter notice, F. CAJORI, (2) vI, 255-257. (Opinions et curiosites touchant la mathematique d'après les ouvrages francais des XVI ${ }^{\mathrm{e}}$, XVII ${ }^{\mathrm{e}}$, et XVIII ${ }^{\mathrm{e}}$ siecles, G. Maupin, 1898.)

V1, Shorter notice, F. CAJORI, (2) VI, 257-258. (La mathematique: philosophie, enseignement, C. A. Laisant, 1898.)

V1, The doctrine of infinity, E. R. HEDRICK, (2) IX, 263-268. (Die Grundsätze und das Wesen des Unendlichen in der Mathematik und Philosophie, K. Geissler, 1902.)

V1, (Q1a, (2) VI, 287-299; (2) Ix, 158-165; (2) x, 1-23).

$\mathbf{V} 1 \mathbf{a}, \mathbf{K}$, The teaching of elementary geometry in German schools, A. ZiweT, I, 6-12. (Inhalt und Methode des planimetrischen Unterrichts, H. Schotten, 1890.)

V1a, On the teaching of elementary geometry, E. W. DAvIs, III, 8-14. (Plane geometry, on the heuristic plan, G. I. Hopkins, 1891; Elementary synthetic geometry, N. F. Dupuis, 1889; Introductory modern geometry, W. B. Smith, 1893; Elementary synthetic geometry, G. B. Halsted, 1892.)

V1a, Shorter notice, T. S. FIske, (2) I, 76-77. (Le livret de l'étudiant de Paris, 1894.)

V1a, Shorter notice, J. W. A. Young, (2) v, 262-264. (Lectures on elementary mathematics, J. L. Lagrange, translated by T. J. McCormack, 1898.)

V1a, Encyklopïdie der Elementar-Mathematik, D. E. Sмrтн, (2) x, 200-204. (Encyklopädie der Elementar-Mathematik, ein Handbuch für Lehrer und Studierende, H. Weber und J. Wellstein, Band I: Elementare Algebra und Analysis, H. Weber, 1903.)

V3, 4,5, Shorter notice, D. E. SмIтH, (2) vIII, 353-355. (Histoire des mathématiques dans l'antiquité et le moyen age, H. G. Zeuthen, traduite par J. Mascart, 1902.) 
V3b, K, Euclid's Elements, J. L. CooLIDGE, (2) vil, 216-220. (Euclid und die sechs planimetrischen Bïcher, M. Simon, 1901; The contents of the fifth and sixth books of Euclid, arranged and explained by M. J. M. Hill, 1900.) Reply to Mr. J. L. Coolidge's review of Hill's Euclid, M. J. M. HiLl, (2) viIr, 479-481.

V4c, U, Shorter notice, E. W. Brown, (2) vII, 188-190. (Die Mathematiker und Astronomen der Araber und ihre Werke, H. Suter, 1900.)

V5b, 6, Shorter notice, D. E. SмITH, (2) Ix, 123-125. (Urkunden zur Geschichte der Mathematik im Mittelalter und der Renaissance, Theil 1, M. Curtze, 1902.)

V8, Shorter notice, A. Ziweт, (2) III, 256. (Index operum Leonardi Euleri, J. G. Hagen, 1896.)

V9, Klein's Evanston lectures, H. S. WIIITE, III, 119-122. (The Evanston colloquium, F. Klein, reported by A. Ziwet, 1894.)

V9, Bibliography of mathematical dissertations, E. M. BLAKE, III, 125127. (Catalogue des thèses de sciences soutenues en France de 1810 à 1890 inclusivement, A. Marie, 1892; Verzeichnis der seit 1850 an den deutschen Universitäten erschienenen Doctor-Dissertationen und Habilitationsschriften aus der reinen und angewandten Mathematik, 1892.)

V9, B4, Meyer's Report on the theory of invariants, F. FrankLIN, III, 187-190. (Bericht über den gegenwärtigen Stand der Invariantentheorie, W. F. Meyer, 1892.)

V9, Shorter notice, A. Ziwet, (2) I, 75-76. (Jahresbericht der Deutschen Mathematiker-Vereinigung, Band 3, 1893.)

V9, Shorter notice, A. ZiweT, (2) I, 125-126. (Lobachevsky memorial volume: 1793-1893, 1894.)

V9, Papers of the mathematical congress, H. B. FINE, (2) II, 327-329. (Mathematical papers read at the International Mathematical Congress held in connection with the Workd's Columbian Exposition, Chicago, 1893, 1896.)

V9, U, Shorter notice, E. W. Brown, (2) III, 225-227. (The scientific papers of John Couch Adams, W. G. Adams, volume I, 1896.)

V9, Plücker's Collected papers, C. A. ScoтT, (2) IV, 121-126. (Julius Plückers gesammelte mathematische Abhandlungen, A. Schoenflies, 1895.)

V9, Galois's Collected papers, J. Pierpont, (2) v, 296-300. (Oeuvres mathématiques $\mathrm{d}^{2}$ Evariste Galois, 1897.)

V9, Shorter notice, E. O. LoverT, (2) virr, 352. (Karl Friedrich Gauss:-General investigations of curved surfaces of 1827 and 1825, translated by J. C. Morehead and A. M. Hiltebeitel, 1902.)

V9, Shorter notice, M. Bôcher, (2) Ix, 125-126. (Gauss's wissenschaftliehes Tagebuch, 1796-1814, 1901.)

V9, Shorter notice, C. A. ScotT, (2) Ix, 214-215. (Compte rendu du deuxième congrès international des mathématiciens tenu à Paris du 6 au 12 aont, 1900, E. Duporcq, 1902.)

V9, Gauss's Collected works, J. Pierpont, (2) Ix, 357-369. (Carl Friedrich Gauss Werke, Band 8, 1900.) 
V9, Shorter notice, E. W. Brown, (2) x, 204-205. (Mathematical papers of the late George Green, N. M. Ferrers, facsimile reprint, 1903.)

V9, Shorter notice D. E. SмrтH, (2) x, 261-263. (Mathematischer Bücherschatz, Teil 1: Reine Mathematik, E. Wölffing, 1903.)

V9, Shorter notice, E. B. Wusson, (2) x, 516. (Carl Anton Bjerknes: Gediichtnisrede, V. Bjerknes, 1904.)

V9, (J4, (2) IX, 557-558; Q1b, (2) vr, 339-344).

V10, Shorter notice, D. E. SмITH, (2) IX, 218-219. (Annuaire des mathématiciens, 1901-1902, C. A. Laisant and A. Buhl, 1901.)

X.

Processes of calculation; tables; nomography; graphic methods of computation; planimeters; various instruments.

X2, H5i $a$, Table of the first forty roots of the Bessel equation $J_{0}(x)=0$ with the corresponding values of $J_{1}(x), \mathrm{R}$. W. WILlson and B. 0 . Peirce, Sept. 1, 1896, (2) III, 153-155.

X2, (I12, (2) vIII, 401-402).

$\mathrm{X},(\mathrm{A5b}$, (2) vI, 402-404).

X2, Eight figure logarithm tables, H. JAсову, I, 139-140. (Tables des logarithmes à huit décimales des nombres entiers de 1 à 120000 , 1891.)

X2, A new logarithmic table, H. JACOBY, II, 33-34. (Tables des logarithmes à huit décimales des nombres de 1 à 125000 , J. de Mendizabal y Tamborrel, 1891.)

X2, Shorter notice, E. W. BRown, (2) IV, 236-237. (Fünfstellige Tafeln und Gegentafeln für logarithmisches und trigonometrisches Rechnen, H. Schubert, 1897; Tafeln zur Berechnung der reellen Wurzeln sämtlicher trinomischer Gleichungen, etc., S. Gundelfinger, 1897.)

X2, Shorter notice, E. O. LoverT, (2) V, 261-262. (Formulario scolastico di matematica elementare, M. A. Rossotti, 1899.)

X2, Shorter notice, E. W. Brown, (2) vI, 116-117. (A short table of integrals, B. O. Peirce, 189.9.)

$\mathbf{X} 2$, Shorter notice, E. W. Brown, (2) x, 516-517. (Tablas de multiplicar, J. de Mendizabal y Tamborrel, 1903.)

X2, (I25b, (2) III, 399-401).

X3, Shorter notice, F. Morley, (2) vI, 398-400. (Traité de nomographie, M. d'Ocagne, 1899.$)$

X4, Willson's Graphics, J. B. Chrtmenden, (2) v, 353-357. (Theoretical and practical graphics, F. N. Willson, 1898.)

X8, Shorter notice, V. SNYDER, (2) X, 209-210. (Catalog mathematischer Modelle für den höheren mathematischen Unterricht, $\mathbf{M}$. Schilling, 1903.)

X8, ( $\left.\mathbf{M}^{3} 5,(2) \times, 409-410\right)$. 
Reports of MeE'rings.

Mectings of the American Association for the Advancement of Science:

1893, Madison, C. A. WALDo, III, 20-22;

1894, Brooklyn, E. M. Blake, (2) I, 16-20;

1895, Springfield, L. L. CoNANT, (2) II, 7-11;

1897, Detroit, J. McMahon, (2) IV, 48-53;

1898, Boston, J. McMahoN, (2) v, 87-105;

1899, Columbus, G. A. Miller, (2) vI, 57-62;

1900, New York, G. A. Mrller, (2) vII, 79-87;

1901, Denver, G. A. Miller, (2) viII, 71-81;

1902, Pittsburgh, E. S. CRAwLEY, (2) IX, 94-106;

1903-1904, St. Louis, L. G. WeLd, (2) x, 287-293.

Meetings of the American Mathematical Society:

Summer meetings have been reported regularly in the BuLLETIN since the first held in 1894; the series of extended reports of all meetings, including those of the Chicago and San Francisco Sections, begins in second series, volume 4 of the BuLletiN, previous meetings having been briefly reported in the NoTEs. The summer meetings, 1894-1903, were held in the following sequence of place:

1894, Brooklyn, N. Y.;

1895, Springfield, Mass.;

1899, Columbus, O.;

1896, Buffalo, N. Y.;

1897, Toronto, Can.;

1898, Boston, Mass.;

1900, New York, N. Y.;

1901, Ithaca, N. Y.;

1902, Evanston, Ill.;

1903, Boston, Mass.

Colloquiums of the American Mathematical Society:

1896, Buffalo, T. S. Fiske, (2) III, 49-59;

1898, Cambridge, H. S. White, (2) v, 57-58;

1901, Ithaca, E. KASNER, (2) vIII, 22-25;

1903, Boston, F. N. Cole, (2) X, 119-120.

Centenary of the birth of Abel, E. B. WILson, (2) IX, 154-157.

Meetings of the Deutsche Mathematiker-Vereinigung:

1S91, Halle, A. Zrwer, I, 96-101;

1899, Munich, J. Pierpont, (2) vi, 282-287;

1901, Hamburg, C. M. Mason, (2) vin, 113-122;

1902, Carlsbad, C. M. Mason, (2) IX, 206-214;

1903, Cassel, R. E. Wilson, (2) x, 230-239.

International mathematical congresses:

1893, Chicago, H. W. TyLI:R, III, 14-19;

1897, Zürich, W. F. Osgood, (2) IV, 45-47;

1900, Paris, C. A. ScotT, (2) vII, 57-79.

Mathematics at the International Congress of Philosophy, Paris, 1900, E. O. Lovett, (2) vII, 157-183.

Notes.

The Bulletin gives in the Notes a chronicle of current events in the mathematical world. Here are to be found items regarding the American Mathematical Society and other scientific societies and academies representing mathematical interests, lists of the contents of 
various mathematical journals, publishers' announcements of forthcoming mathematical books, brief accounts of mathematical prizes, university courses in mathematics, appointments, and other personal news.

\section{New Publications.}

Under this heading each number of the BULLETIN contains a complete bibliography of recent mathematical works.

\section{Annual List of Papers.}

In this list, which is published in the final number of each volume of the Bulletin, are to be found the titles of papers read before the American Mathematical Society and subsequently published, together with the date of reading and a reference to the place of publication. 